\title{
The Osirian Cult in Temples' Crypts in Egypt during the
}

\author{
Greco-Roman Period
}

\author{
Sara El-Sayed Kitat
}

\section{Faculty of Tourism and Hotels Alexandria University}

\begin{abstract}
Textual and iconographic evidences confirm the existence of the Osirian cult in the crypts of the temples which were regarded as the tomb of Osiris. Wabet rooms were connected with Osiris as the cult of solar deities was identified with the funerary function of Osiris by the late Period. Temples' crypts became the starting point of the Osirian festival of Khoiak. This is attested in the temples of Denderah, Edfu, Aramant, and Opet temple. In the crypts of Armant, Osiris was connected with Montu and was identified with god Sokar in the crypts of Edfu. The Osirian ritual of giving cool water is represented in the Crypts of Denderah. Crypts nos. 1 and 2 in Edfu temple were consecrated to preserve the reliquary leg of Osiris. The khekeru frieze and the hwt bennu sign, which were connected with the Osirian cult, appeared on a large scale in the temples' crypts.
\end{abstract}

Keywords Crypt, Osiris, Denderh, Edfu, Opet, Armant

\section{Osiris; a God dwelled in the Darkness of Temples' Crypts}

Osiris was described to be god of the Underworld who dwelled in the darkness; a description which perfectly applies on the crypt of the temple immersed in darkness away from the eyes of the worshippers. The cult of god Osiris gained a remarkable importance in the crypts of the temples'; a phenomena that spread on a wide scale during the Greco-Roman period. Throwing the light on the Osirian existence in these hidden places led us to

'D. Kurth defined the word "crypt" as a "hidden chamber in the temple, often underground, but frequently also in the upper parts of the temple. Place where cult statues and ritual equipment were kept". As for Sylvie Cauville, she identified the crypt as "a room - usually long and narrow - arranged inside the walls and in which objects of worship and divine statues were kept; Kurth, 2004, p.71; Cauvile, 1990, p. 1. 


\section{The Osirian Cult in Temples' Crypts in Egypt during the Greco-Roman Period}

analyze the main reasons behind the cultic centralization of Osiris in the temples' crypts.

The crypt was regarded by the ancient Egyptian the tomb of Osiris where the king could identify with him. This concept appeared firstly in the Pyramid architecture in Egypt. According to the Pyramid Texts of King Unas, the "old" king entered his "crypt" at the sunset being identified with god Re-Atum the manifestation of the evening sun. The word "crypt" here refers mainly to the burial chamber inside the pyramid. In the crypt, the king spent the night and by this way became united with Osiris god of the Otherworld in the fusion of the royal mummy of the king. At the sun rise, the deified king left his resting place through the antechamber of the crypt and starts a new life ascending to the sun rise in the form of god Rehorakhty ${ }^{r}$. By the fifth dynasty, the offering halls were introduced to the pyramids architecture in Egypt. Thus, the king received food offerings in his crypt and left after that by using the false door. This ritual was documented in the Pyramid Texts as well as Abusir Papyri which were archived from the funerary temple of Neferkare Neferefer'.

Regarding the crypt of the temple as the tomb of Osiris continued to be found in the temples' architecture. Many historians declared the sacred religious function of these hidden places. For instance, Plutarch described these galleries to be "the place for gods". The crypt in Hibis temple at Kharga Oasis was used as a sacred tomb for god Osiris ${ }^{\circ}$. A staircase gives access to a shaft-designed crypt which lies beneath a chamber which was consecrated for the cult of Osiris". Texts of Denderah temple describe the crypts as "mysterious corridor" leading to the "mysterious places" in connection with the ceremonies of the New Year". In Edfu temple, certain texts throw the light on the religious function of these places. They were described to be "chapels of the deities" for the Ennead, and "his chapel hidden in its hidden place" ". This unnamed divinity is most probably Osiris

\footnotetext{
Arnold, 1997, p. 71; 267, note 119-121.

Arnold, 1997, pp. 71-72

'Traunecker, 1980, col. 827; Meunier, 1942, p. 148.

- Traunecker, 1994, p. 25.

Traunecker, 1994, p. 25; Winlock, 1938-1941, pp. 10-13, pl. 33, 37.

Edfou I 76 (8) and 82 (12-13); Daumas, 1951, p. 393 n.1; Traunecker, 1994, pp. 38, 46, note 55 .

${ }^{\wedge}$ Edfou VII 12(5); Traunecker, 1994, pp. 37; The location of the crypts confirms the usage of these hidden places in certain sacred rituals. Almost all crypts are located beneath the sanctuaries of the temples and provided with a sealed closing system. Using sliding slabs and wooden locks appeared in the crypts of Opet at Karnak. The crypts of Denderah present the most harmonious type of crypts of three levels covering the whole structure of the temple
} 
hiding in a secret place of the temple. Part of the inscriptions of the naos of Edfu temple says; "his crypt is deep, all his walls and roofs are inaccessible" "These walls and roofs, which cannot be accessed by the visitors or the ordinary officials, apparently refer to the maze of crypts hidden in the thickness of the walls'. Texts of Edfu temple which describe the procession of the New Year festival refer to the crypts as "chapels" and "the holy place"".

Both the southern crypt no.4 and the western crypt no. 3 of Denderah temple represent the pantheon of Edfu and Denderah. The two crypts represent the pantheons of Dendrah and Edfu through two interfacing walls; the southern and northern walls in southern crypt no. 4 and the western and eastern wall in the western crypt no. $3^{r}$. According to the depicted scenes, the pantheon of Denderah consisted of eleven deities; Osiris is depicted as the tenth one in order and was named; "Osiris (the victorious Ouennefer) the great god which takes his place in Iounet"' (fig.1.a). On the other hand, the pantheon of Edfu consists of eleven deities. Osiris is depicted here as the ninth god and was named; "Osiris the Heliopolitan, the great god which takes his place in Edfou" " ' (fig.1.b).

In Denderah temple, the western crypt no. 1 (chamber C) has a certain significance in the Osirian cult ${ }^{10}$. In this chamber, on its eastern wall, the shape of Osiris on his throne is also depicted ${ }^{17}$ (fig.2). He is depicted wearing the Osirian crown and holding the royal insignia. Isis and Nephtys are depicted flanking the figure of the seated god.

In Edfu temple, mainly in the second chamber of Osiris (room $\mathrm{H}$ ), the complete myth of Osiris and his resurrection was inscribed on the wall. These

and sealed with sliding slabs. In addition, the crypts were intended to be designed as hidden places in the temples away from the eyes of common people and were only known by the high priests of the temples; Traunecker, 1980, cols.823-826.

${ }^{\wedge}$ Traunecker 1980, cols. 823-826; Edfou II, pl. 25 a; Traunecker, 1994, pp. 21-22; Cauvile, 1990, pp. 54-55; Daumas, 1969, pp. 62-63; Moharram, 2000, pp. 445, 448; Pieron,1910, p. 71.

${ }^{9}$ Edfou IV, 12 (9); Traunecker, 1994, pp. 37.

'. Traunecker, 1994, pp. 37.

"Traunecker, 1994, pp. 38-39.

ir Cauville, 2004, pp. 59-60; Den. VI, 57-64.

${ }^{1 T}$ Cauville, 2004, p. 60; Den. VI, 61-64, and 159-162.

Is Cauville, 2004, p. 60; Den. VI, 58-60 and 169-173

${ }^{10}$ Waitkus, 2007, p. 345; Waitkus,1997, p. 247; Cauville, 2004, p. $31 \mathrm{ff}$; the same frieze of the Osirian chapel on the roof of the temple, Dendara east no. 3; Dendara XI, pl. X 87 and 90,92

"Dendara VI, pl. XLVII, pl.LIV details from pl. DXXIII, Chamber C 


\section{The Osirian Cult in Temples' Crypts in Egypt during the Greco-Roman Period}

texts were recited by the priests of Edfu during the Osirian festivals ${ }^{\prime v}$. On the west wall of (room $\mathrm{H}$ ) that gives accesses crypts nos. 3, 4 and 8 , god Osiris is depicted seated on his throne ${ }^{\prime}{ }^{\wedge}$. This scene is the solemn scene of offerings in this room. The first register represents Horus and Hathour receiving their offerings. The second register shows god Osiris seated on his throne which is placed inside the canopy used during the $h b s d$ festival. This canopy was used during the royal jubilees referring to Osiris eternity. The representation of the štyt $\mathbf{W}$ evokes the sh-ntr sign of Anubis which god Sokraris used to receive offerings during the ritual of the opening of the mouth and receiving both the ankh and was symbols. This rite was one of the stages of the Khoaik festival of Osiris who is accompanied with Isis and Nephtys in this scene ${ }^{19}$. Thus, the second register shows Osiris of Behdet identified with the dead king, who receives purification with his two sisters. In the third register, another rite is performed. In this part, Osiris Sokaris receives the funeral ritual to be reborn again during the morning in the north ${ }^{\text {r. }}$ (fig.3).

According to the inscription of crypt no.1 of Armant temple, Osiris was venerated as god of the Otherworld where darkness dwells in the crypts. He was described as "Osiris who presides over the west (ounnefer), king of the two, who lives in Ermant" "r . On the west wall of this crypt, there is a large hymn of thirty-four columns forming part of the Hours of the Day ${ }^{r r}$. The presence of this text throws the light on certain Osirian rituals which were described to be performed during the hours of day and night ${ }^{r r}$. Flanking the entrance to crypt no. 2 of the same temple, there are representations of bullheaded gods holding ropes in their hands ${ }^{\text {r }}$ (fig.4.a). This iconography also confirms the role of these deities to control over animals or harmful

\footnotetext{
Cauville, 1983, p. 25; Edfou I, 204, 13-14

'^ Traunecker, 1994, p. 29, fig. 3; Cauville, 1983, p. 26, fig.3.

${ }^{19}$ In the left part of the second register, Ptolemy IV Philopater presents offerings to Osiris of Behdet and Isis. The accompanied texts of Osiris says; 'I give you the South in adoration before your white crown, The North in jubilation before your red crown, the west and east under your red crown; the Nine Arcs being united under your sandals'. On the right side of the same register, Ptolemy IV presents his offerings to Osiris of Behdet and Nephtys. The inscription accompanying Osiris says; 'I give you a fast Nile on its time to inundate your fields as it should. It comes at its time of year to make the fields fertile with fresh plants'; Cauville, 1983, pp. 27-29

Cauville, 1983, pp. 25-27.

"Thiers Ch. \& Volokhine, p. $\uparrow$.

Thiers \&Volokhine, 2005, pp. 68-69; Waitkus, 2007, p. 342.

"Thiers \&Volokhine, 2005, p. 69

${ }^{r}$ Thiers \&Volokhine, 2005, pp. 70-72; Waitkus, 2007, pp. 342, 344.
} 
enemies $^{\text {ro }}$. It recalls the shape of the slaughter house of Osiris in chapter 17 of the Book of the Dead ${ }^{r}$. In this chapter, the slaughter house of Osiris where his enemies were killed, was depicted and led by an animal-headed deity who is holding knives in his hands (fig.4.b) The accompanied texts of the chapter says; ' Who is he? It is the one who uses his hand on that night of reckoning up the robbers, on that night of the flame against the fallen, when

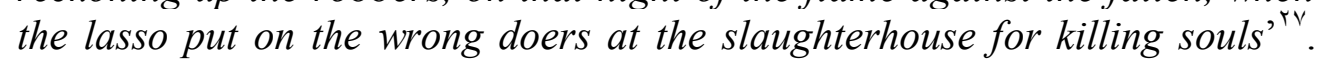
Thus, this scene in the crypts of Armant recalls the function of Osiris as a defender of his enemies and confirms the function of the crypts as a sacred place for the cult of Osiris.

Among the depicted divine statues in the crypts of Denderah temple ${ }^{r \wedge}$, the sacred statues of Osiris were depicted as a flacon-shaped statues $p 3 \mathrm{hm}$ in the eastern chamber no. 1 (chamber $\mathrm{C}$, eastern wall) ${ }^{\text {rq }}$ (Chamber $\mathrm{G}$, western wall) ${ }^{r \cdot}$ and (Chamber A, western wall) ${ }^{r}$. Statues of Osiris are also represented on the walls of the crypts as mummified figure wearing the Atef crown in the eastern crypt no. 1 (chamber E, west wall) $)^{r r}$ western crypt no. 1 (chamber A, west wall) ${ }^{r r}$ and (Chamber D, west wall) ${ }^{r \varepsilon}$.

The procession of the divine statues of the temple started from the temple crypts where they were preserved. Thus, the ceremony began from the darkness of the crypt, representing the netherworld of Osiris or the tomb to the sunlight outside the temple. This divine procession resembles the journey of the sun evoking the concepts of renewal and rebirth and was confirmed

\footnotetext{
${ }^{\text {ro }}$ Thiers \&Volokhine, 2005, pp. 69-71; Goyon, 1999, p. 80, col. 37, 1, pl.33 A.

r Thiers \&Volokhine, 2005, pp. 70-72; The gods holding ropes were depicted under the throne of Osiris in a scene from the Book of the Night; Thiers \&Volokhine, 2005, pp. 69-71; Roulin, 1996, pp. 254-257, 259-261 (8e heure), pl. XII.

${ }^{r V}$ Thiers \&Volokhine, 2005, pp. 69-71; Von Dassow, 2008, pp. 101-102; Hornung, 1990, p. 76.

${ }^{\wedge}$ Cauville analyzed the inscription of the Dendarah crypts and recorded 162 types of preserved statues which reached the number of 284 and placed in four main crypts. In addition, the inscribed texts mention the preservation of musical instruments, sacred symbols, and figures in the shape of cows, falcons...etc. The majority of the statues reach the height of $52.5 \mathrm{~cm}$ and most of them were made of gold beside copper and gilded bronze and in less number wood. The eyes of the statues were inlaid and the hair was gilded; Traunecker, 1994, p. 23 note 11,12; 109, note 4; Cauville, 1987, pp. 79-117; Hoffman, 2002, pp. 109-119.
}

Cauville, 1987, p. 1.1; D. V, 15, 9, pl. 336

Cauville, 1987, p. 1. '; D. V, 15, 9, pl. 336

Cauville, 1987, p. ' • '; D. VI, 71, 10, pl. 512

${ }^{r}$ Cauville, 1987, p. 1 । '; D. V, 29, 7, pl. 343

${ }^{r r}$ Cauville, 1987, p. 1. '; D. VI, 71, 4, pl. 512.

${ }^{r \varepsilon}$ Cauville, 1987, p. 1.'; D. VI, 87, 16, pl. 527. 


\section{The Osirian Cult in Temples' Crypts in Egypt during the Greco-Roman Period}

through the architectural design of the temples. The statues of the deities were preserved in the sanctuary or crypt immersed in darkness, and on their way out, they gradually entered much larger and brighter halls, till they reached the pylon of the temple like the shining sun in the horizon ${ }^{\text {ro }}$.

During their processional way, the statues of the gods were carried in from their residence in temple's crypts to the wabet complex ${ }^{r "}$ which consists of an open court, and a slightly elevated chapel. In this chapel, the divine statues were purified, clothed, and adorned ${ }^{p \gamma}$. After that, the procession continued to a kiosk or upwards to the roof of the temple, where they were exposed to the sunlight reuniting with their $b a$, or their "divine manifestation" by performing the rituals of the "opening of the mouth"

By the Ptolemaic period, the wabet rooms became connected with the Osirian cult as the cult of solar deities was gradually identified with the funerary function of Osiris by the late Period. The edifice of Taharqa in Karnak presents a clear example of the assimilation between the funerary sphere of Osiris and the solar cult. In addition, the monumental tombs of in Assasif housed large open courts which seemed to be a striking devolvement in the funerary architecture in Egypt. Thus, the large court of the wabet chapel exposed to the sun light might symbolize the victory of the sun over death. In other words, the presence of court exposed to the sun in the wabet rooms symbolize the renewal, and the rejuvenation of the deceased who became ready for his new life as it became incorporated in the temple and solar liturgy during that time ${ }^{r q}$.

The crypts of the Opet temple " were related to the rites performed in the wabet of the temple ${ }^{\varepsilon !}$. It is known that the north sanctuary, where the crypt is

ro Coppens, 2009, p. 2; Finnestad,1997, p. 216; Waitkus, 1997, 47, pp. 254 - 256, 258, 262 272.

The wabet kiosk played a crucial role during the first feast Htp tpy which occurred during the last days of the old year and the first days of the New Year. In this place, the statue of the main deity of the temple was exposed to the sun rays through a rite of the 'union with the sun disc' hnm itn achieving by this way the rejuvenation and the renewal of the divine statues in the temple; Coppens F. (May 2009). In Preparation for Regeneration; The Wabet in Temples of the Ptolemaic and Roman Period. The Heritage of Egypt, (fifth issue), pp. 35-36.

${ }^{r v}$ Coppens, 2009, p. 4; Traunecker, 1995, pp. $241-282$.

${ }^{\top \wedge}$ Coppens, 2009, p. 4; Alliot, 1949-1954, pp. 303-433; Cauville, 1984 Edfou, pp. 73; Cauville, 2002, pp. 35- 49; Daumas, 1969, pp. 96 - 101; 1982: 466 - 472; Fairman, 19541955, pp. 165 - 203, 183-189.

ra Coppens, 2009, 39.

" The crypt complex of this temple is located in the rear south west corner behind the sanctuary. They were formed in the shape of subterranean galleries circulating the sanctuary of the temples and are possibly linked with the chambers around the temple's sanctuary like the crypts of Edfou and Dendara. The decoration of the rooms and the cartouches date back 
found, served as a place for the ceremonies commemorating the resurrection of Osiris. This is confirmed by the representation of certain pieces of the religious furniture, particularly the funerary bed and a statue of Osiris ${ }^{\text {}}$. According to the texts and scenes in the crypts of Denderah temple, statuettes of Hathour and the ritual objects of the New Year ${ }^{2 r}$ were preserved in the southern crypt no. A. The texts inscribed in the entrance of this crypt describe the ceremonies held in the wabet which was connected to the Osirian chapel on the terrace of the temple ${ }^{\varepsilon \varepsilon}$ One of the two crypts discovered in the Roman temple of Shenhur ${ }^{20}$ is located beneath the pavement of the wabet ${ }^{\text {s }}$.

\section{Temples' Crypts and the Festival of Khoaik}

The festival of Khoaik was celebrated in certain temples during the Graeco-Roman Period being of the major festivals for god Osiris ${ }^{\varepsilon \vee}$. According to Plutarch, this festival began on the nineteenth day of the month of Athyr ${ }^{i \wedge}$. It included both public ceremonies and sacred rituals as well ${ }^{\varepsilon ?}$.

to the reign of Ptolemy XII Neos Dionysus Auletes; Thiers, \& Volokhine, 2005, pp. 1, 9-10, fig. 1: Waitkus, 2007, p. 342; Traunecker, 1994, p. 21-46; Traunecker, 1980, cols. 823-830.

¿ Traunecker, 1980, cols. 824-825; Varille, 1942, p. 135.

\&r Traunecker, 1994, p. 42, 46, note 64; de Witt, 1958, p. 120.

${ }^{2}$ The crypts of Dendarah temple were a place for preserving the statues of the deities which were used in the various sacred ceremonies. According to the inscribed text of the western pier of the southern crypt no.1, this crypt was used by the goddess to enter the settlement of the sacred statues before and after the festival of the New Year. Calude Traunecker defined four main functions of the crypts of Dendarah temple. They were used as a conservatory of ancient divine statues of goddess Hathour during the festival of the New Year. They were also used as a resting place for particular statues in certain rituals. The walls of the crypts can reproduce fundamental texts of local theology. Finally, the crypts also served as reservoir for liturgical equipment. Other scholars merely believe that these hidden places housed a certain magical power. Thus, it could be said that the crypts of the temple were a sort of hidden treasury to preserve the most sacred equipment of the temple by the priests. For further detail see; Traunecker, 1994, p.23, 38; Daumas, 1951, p. 393; Dendara V, p. 118 (1); Cauville, 1990, 54-55; Pieron, 1910, pp. 71-72; Moharram, 2000, p. 448.

$\leftleftarrows$ Traunecker, 1994, p.38.

¿o De Meyer M., \& Minas-Nerpel, 2012, p. 2; Traunecker, 1994, p. 40.

"De Meyer\& Minas-Nerpel, 2012, 2.

¿ Bonneau, 1964, pp. 252, 368; Dunand \& Zivie - Coche, 1991, pp. 311-312; Rossini \& Anteleme, 1992, p. 147; Wilkinson, 2000, p. 122.

${ }^{\circledR A}$ Wiedemann, 1903, p. 44.

" The festival began with placing the statue of the god inside his nechmet boat that was guarded by wepwawat. On the board of this boat, it was believed that Osiris fought his enemies. Plutarch described many rituals of this festival. It included a black bull with golden horns, covered with a blanket. Black color represents the grief of Isis on her lost husband. The priests appeared with golden bowls in which they poured water. People began to scream 


\section{The Osirian Cult in Temples' Crypts in Egypt during the Greco-Roman Period}

Sacred rituals were practiced in the temple of the deity away from the crowds. The main purpose behind these rituals was to achieve the mystical resurrection of Osiris ${ }^{\circ}$.

Symbolizing the tomb of Osiris, temples' crypts became apparently starting point of the festival's celebration. Certain papyri describe the ceremonies of this festival, mainly the Papyrus of Vatican (38608), pCGC $581010^{\circ}$. The first papyrus is concerned with the rebirth of Osiris which occurred in the temple of Opet at Karnak ${ }^{\circ r}$. This festival was described by the inscription of the temple of Denderah ${ }^{\circ r}$ and Plutarch ${ }^{\circ}$. Furthermore, texts and scenes of Opet temple and Armant temple throw the light on this Osirian celebration $^{\circ 0}$. Various rituals were recited on the $26^{\text {th }}$ of Khoaik, at the time of revival of Osiris. This day was described to be "divine morning" which correspond with "the passage from the status of dead god to that of the rising solar god" (feast of Sokar) ".

The temple Opet was a place of remarkable Osirian festivals which were spectacular as well as rare. These celebrations were held to recall the phases of the Osirian myth in the secret crypts of the basement and the corresponding chambers. Concerning the two crypts of floors whose function is still obscure, they housed once divine images ${ }^{\circ y}$. Short-termed celebrations were apparently held in the central sanctuary during the year. Thus, the importance of this temple was annually revived during the great Osirian festivals. The sealing blocks of the crypts were removed and the preserved cultic objects and images were involved in these celebrations ${ }^{\text {on }}$.

The two crypts of the Opet temple flank the sanctuary and open to two rooms which were consecrated for the worship of the temple as they preserved the sacred objects of Osiris and Isis. These objects inhabited by the

announcing that Osiris was finally found. They mixed earth with water and burnt their finest type of incense and made small images in the form of a crescent to be the manifestation of the watery nature of this deity. After that, the decline of the Nile inundation was symbolized by the kill of Osiris by his enemies. Osiris was carried in a funeral procession called Peker (a ritual practiced at Abydos); Bonneau 1964, p. 250, 368; Rossini \& Anteleme 1992, p. 147; Mallet1888, 43-45.

- Rossini \& Anteleme 1992, p. 147; Kaper, 2008-2009, pp. 31-32; Cauville, 1997, p. 177.

- Thiers \&Volokhine, 2005, pp. 77-79; Waitkus, 2007, p. 344.

or Thiers \&Volokhine, 2005, pp. 77- $\vee 9_{-}$; Herbin, 2003, p. 75, n. 23-24.

${ }^{\circ}$ Wiedemann 1903, p. 3; Armour \& Baker,1986, p. 45; Dunand \& Zivie - Coche 1991, pp. 311-312.

${ }^{\circ}$ Wiedemann 1903, pp. 2-3.

Thiers \&Volokhine, 2005, pp. 77-79; Waitkus 2007, p. 344

Thiers \&Volokhine, 2005, pp. 77-v9-; Herbin 2003, p. 75, n. 23-24.

Traunecker, 1994, p. 42

${ }^{\circ \wedge}$ Traunecker, 1994, p. 42 
divine $b 3$ confirm the function of this place of as place of worship ${ }^{\circ 9}$. The crypts of the basement of Opet (fig.5) were probably used to preserve the required objects of the Osirian celebrations commemorating his resurrection (no.2) and the birth of Horus (no.1). The sealed closing systems of the crypts suggest their occasional usage during ceremonies which apparently took place in the hypostyle hall and the terrace ".

Statues were discovered in the crypts of the Opet temple at Karnak. They were found in crypts (no. 4 and 5, fig.5) beneath the northern worship halls (resurrection of Osiris) and southern halls (the birth of Horus). In the northern crypt (no. 5, fig.5), various life-size statues were found; one of them is made of black bronze with a dimension of $1.75 \mathrm{~m}$. The statue is empowered with the vital powers of the ten Bas of Amun that are solemnly represented only in this place of temple ". Thus, the northern crypts represents represent schemes of the myth of Osiris' resurrection empowered by the ten bas of god Amun which are represented through the discovered objects. Concerning the southern crypts, they contained a statue of Isis nursing her son Horus $(1.08 \mathrm{~m})$. This statue was probably used to reflect the union between the $B a$ of Isis and its statue ${ }^{T r}$.

Directly beneath the shrine of Opet Temple, there is a crypt arranged to receive the statue of goddess Isis. This statue was placed to stand above the recess where the relics of god Osiris must have been kept ${ }^{T r}$. Being the place which recalls the birth of Osiris, the location of the Isis statue in the crypt directly beneath the shrine of the temple commemorates this sacred event.

Charloux with his excavation team ${ }^{15}$ discovered in $2006-2007^{10}$ a staircase located between the southwest gate of the courtyard of the temple of

Khonsou and the back of the temple of Opet ${ }^{14}$. A $2.30 \mathrm{~m}$ long and only $1.10 \mathrm{~m}$ wide staircase was found at the rear back of the sanctuary (fig.6). Sandstone blocks were used to construct this staircase which is supported

\footnotetext{
${ }^{\circ 9}$ Traunecker, 1994, p. 36

"Traunecker,1980, pp. 824-825; Varille, 1942, p. 135; Thiers \& Volokhine, 2005, p. 77.

"Traunecker, 1980, 825.

Traunecker, 1980, cols. 825-826; Witt, 1958, pp. 139, 6.

"Murray, 1931, p. 101.

1క Supreme Council of Antiquities, Ministère des Affaires Étrangères, Européennes, et Centre National de la Recherche Scientifique, \& Franco-Egyptian Center of the Temples of Karnak, 2008, p. 12.

${ }^{70}$ Degardin, 2006-2007, p. 284

"Degardin, 2006- 2007, p. 284.
} 


\section{The Osirian Cult in Temples' Crypts in Egypt during the Greco-Roman Period}

from beneath with two mud-brick walls on each side ${ }^{i v}$. The staircase has the same axis of the door of the outer chapel of Opet ${ }^{\text {}}$.

In the south east corner of the sacred Karnak, the temple of Opet and the temple of Khonsu are located. The back door of the temple of Opet gives access to the chapel located under the sanctuary and the temple itself, corresponding to that of the south-west of the court of the temple of Khonsu. This door confirms that the two temples shared certain religious rituals of Osiris $^{19}$. The function of the staircase is a topic of debate. Among the several opinions $^{\mathrm{v}}$, this staircase was apparently used it by visitors, mainly priests, coming from the Khonsu temple to the Opet temple. This hypothesis is confirmed by the location of the staircase, having the same axis of the basement chapel at the rear back of the Opet temple and a side door of the temple of Khonsu. Thus, this staircase suggests the existence of a crypt which was used during foundation rituals ${ }^{\mathrm{V}}$.

The presence of the Osirian cult in the two temples might explain this architectural connection. In the temple of Khonsu, the inscription on the southwest gate of the courtyard describes Osiris-Onnophris as "making it possible in Opet to renew itself ". On the southern wall of the northeast chapel, Osiris-Onnophris is represented lying on his deathbed, watched over by Isis and Nephthys and the $b 3$ bird $^{\Upsilon \Upsilon}$. Furthermore, Khonsu adopted certain aspects from god Osiris representing his death and resurrection. In the north

wall of northern chapel of his temple, Khonsu appeared in the fusion of the mummified Osiris. The living Osiris-Onnophris who appears in the scene of the upper register on the east wall of the $h r t-i b$. The accompanying inscriptions say; "who arises in the form of light beside bnnt (the temple of

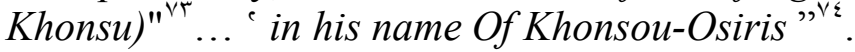

\footnotetext{
${ }^{\top}$ Charloux, 2006-2007, p. 270-271.

Supreme Council of Antiquities, Ministère des Affaires Étrangères et Européennes, et Centre National de la Recherche Scientifique, Franco-Egyptian Center of the Temples of Karnak, 2008, p. 12; Charloux, 2007, pp. 270-271.

${ }^{79}$ Degardin, 2007, p. 283; Degardin, 1985, pp. 115-131.

v. It was assumed that the staircase was used for descending at a time when ground level of the sanctuary was located above. This was confirmed by the threshold of the nearby sanctuary. For further details see; Charloux, 2007, 270-271; Another opinion confirms the existence of an earlier temple For further details see; Supreme Council of Antiquities, Ministère des Affaires Étrangères et Européennes, et Centre National de la Recherche Scientifique, Franco-Egyptian Center of the Temples of Karnak, 2008, p. 12.

"Charloux, 2007, pp. 270-271.

${ }^{r}$ Degardin, 2007, p. 283; Degardin, 1985, pp. 115-131.

${ }^{v}$ Degardin, 2007, 283-284; Mendel, 2003, p. 138; Cauville, 2008, p. 28, n. 33: De Wit, 1968, p. 123, n. 18.
} 
On the other hand, the Osiris myth was represented in the temple of Opet on a large scale. A scene from the north room, mainly in the second register of the north wall, Osiris appears lying on his bed ${ }^{\mathrm{vo}}$. The text under the bed says: "... Nout gave birth to Osiris inside Pr-ipt-wrt, on the western side of the house of Khonsu " between the two temples through Osirian life cycle. Death and regeneration occurred in a perfect harmony between the two temples ${ }^{\mathrm{vv}}$. According to the depicted scenes in the two temples, it could be assumed that the temple of Khonsu which lies in the east became the place of the living Osiris. On the contrary, the temple of Opet which lies to the west became the realm of the deceased Osiris ${ }^{\mathrm{Y}}$.

In addition to the remaining staircase, more than six-hundred graffiti were discovered on the roof of the temple of Khonsu. These inscriptions were engraved by the $w^{c} b$ priests, divine fathers, prophets, lector and chief priests, administrators, scribes, as well as high-ranked clergy. Part of these graffiti represents figures relevant to the lunar cult of Osiris confirming that certain lunar Osirian rituals were performed on the roof of the temple. The figure of a bull, a crescent, the ithyphallic form of god Amun, Khonsu in his naos, the boats of Amun and Khonsu, the baboon with his lunar disk, an obelisk reliquary, and the leg of Osiris are engraved in this place of the temple. This is confirmed by the existence of the crypt looking onto room VI and to the roof $^{1 / 9}$.

The staircase seems be constructed after the decoration of the chapel northeast of the temple of Khonsou (Ramses IV) and before the

establishment of temple of Opet during the Greco-Roman period. The settlement of the staircase gives access to a building at a much lower level than that of the Opet monument which was apparently a subterranean crypt. The narrow width of the staircase suggests that the statue of Osiris was carried in a naos without any divine barks ${ }^{\wedge}$. By this way, it might be assumed that both the Khonsu temple and the Opet temple shared the certain

\footnotetext{
${ }^{\mathrm{v}}$ Degardin, 2007, p. 283;

${ }^{v}$ Degardin, 2007, p. 283; Witt, 1958, pp. 4, 61-63, 118-21.

Degardin, 2007, 283; C. De Wit, 1968, p. 63 B.

Degardin, 2007, pp. 283-284.

Degardin, 2007, p. 284.

${ }^{v a}$ Degardin, 2010, pp. 227-241.

Degardin, 2007, p. 284.
} 


\section{The Osirian Cult in Temples' Crypts in Egypt during the Greco-Roman Period}

Osirian rituals on the roof of the two temples ${ }^{\wedge}$. According to the discovered graffiti, the Osirian rites took place on the roof of the temple of Karnak. Participants of these festivals used the staircase for their descending procession to the Opet temple where they continued their rituals. Finally, the objects were preserved in the crypts of the Opet temple.

In the Opet temple of Karnak, the inscription of Osirian cult throws the light on the resurrection and rebirth of Osiris. On the contrary, the inscription in the crypts of Armant deals with the renaissance of god Montu- Rahorakhty in the fusion of god Osiris ${ }^{\wedge \uparrow}$. The Osirian funerary rites of Djeme include the ritual of opening the mouth by "the primordial gods" "(fig.7).

In crypt $\mathrm{n} 1$, the hymn of the hours of the day is inscribed being related to the Osirian funerary rites. Passing to crypt no. 2 which is devoted to the primordial gods, the Theban Amun is depicted practicing some rites in order to be assimilated with Osiris himself: "Montui Re, mistress of Ermant, king of the gods, Osiris of which the members are complete, father of the fathers of all The gods ". In the same crypt, Montu god of Ermant is represented leaving this complex, passing in front of the hymn of the Hours of the Day inscribed on the west wall of the crypt $n 1$ symbolizing the Osirian rebirth ${ }^{\wedge \varepsilon}$.

The religious relation between Montu and Osiris is emphasized through the rites of Djeme on the $26^{\text {th }}$ of Khoiak and the offerings to the primitive god. Thus, many scholars firstly connected between the crypts of Armant and Taharqa building in Karnak where god Amun completed libation in Djeme. God Montu-Re returned back from Djeme to Armant and appeared in the

crypts no. 1 and 2 in the shape of Osiris ${ }^{\wedge \diamond}$. "Montou Re" Lord of Ermant, king of the gods, Osiris, whose members are full of the fathers of all the gods" ".

On the $26^{\text {th }}$ of Khoaik, as a part of the ritual of the "procession of Sokar", the priests of Karnak went to the temple of Opet in Karnak, after offering their libations. On their way to the temple of Opet, they sang a hymn: " $O$

\footnotetext{
A) The temple of Khonsu houses a subterranean crypt looking onto room VI. For further detail see; Degardin, 2010, pp. 227-241

^r Thiers \&Volokhine, 2005, pp.77-79; Waitkus, 2007, p. 344; The religious assimilation between Montu and Osiris through the flood was also attested at Deir Chelouit where crypts were discovered by Trauneckener; Thiers \&Volokhine, 2005, p. 77; Zivie-Coche, 1986, n. 152, 17; Traunecker, 1994, p.21-22, 44, no. 17; Traunecker 1980, col. 823, no. 10, 22, 26, col. 824, n. 58

^r Thiers \&Volokhine, 2005, p.78-79.

${ }^{\wedge}$ Thiers \&Volokhine, 2005, p. 78-79.

${ }^{\wedge}$ Thiers \&Volokhine, 2005, pp. 77-78; Waitkus, 2007, p. 344.

${ }^{\wedge}$ Thiers \&Volokhine, 2005, p. 77.
} 
Osiris come to your soul ... 'to the end ${ }^{\text {, }}$. Versions of this hymn have been recorded in Ermant's crypt no. 1, as well as in the second part of P. CGC $58010(1.7-12)^{\wedge \wedge}$ and Fr. Vatican $38608^{\wedge 9}$.

Furthermore, the Osirian cult appeared in part of Edfu crypts where Osiris and Sokar where identified together. In Edfu temple, along the wall of the Mesen room, which is located north of the sanctuary, there are chapels dedicated to the cult of Sokar and Osiris ${ }^{9 \cdot}$ or mainly Osiris identified with god Sokaris". Rooms G, H and F, considered as "the palaces of Osiris of Behdet" " ". Room H gives access crypts nos. $3^{9 r}$ and $8^{9 \text { q }}$ (fig. 8 ). This room is called "the Castle of the Prince" ". The function of the Edfu crypts is related to the chapels annexed to the crypts. Being connected with the three chapels of Osiris (chapels G, H, F), crypts nos. 3 and 8 belong to the palace of Osiris and played a certain role in the Osirian celebrations of the month of Khoaik ${ }^{\text {I }}$.

The decoration of chapels of Osirs Sokaris present the mysteries of Osiris which were prepared in the month of Khoaik including all the iconographic and textual elements necessary for the resurrection of Osiris. The first chamber room $(\mathrm{G})$ represents the identification of Osiris with Min and part of

${ }^{\wedge v}$ Thiers \& Volokhine, 2005, pp. 78, 81; Barguet P., (1962). Le papyrus N. 3176 (S) du muse du Louvre, BdE, 37, Le Caire, p.22 (IV, 6).

${ }_{\wedge}^{\wedge}$ Thiers \&Volokhine, 2005, p. 78; Goyon, 1972, pp. 296-299.

${ }^{\wedge}$ Thiers \& Volokhine, 2005, pp. 78-79;

9. Fairman, 1954-1955, pp. 170-171; Arnold, 1997, p. 221; Traunecker, 1994, p.36

") Cauville, 1983, pp. 25-32.

${ }^{9}$ Traunecker, 1994, p. 36; Edfou VII 13 (4); Arnold, 1997, p. 193, fig. 89

${ }^{9 r}$ Crypt no.3: is accessible by a shaft in the northwest hall $(\mathrm{H})$ which is the second chamber of Osiris Sokaris. In the north-west corner of the room, a shaft gives access to a basement crypt of the north wall and is divided into three sections. The first one is occupied by a staircase compensating for the difference in ground level of this part and ground level of the second section which is $145 \mathrm{~cm}$ higher. The third and final section is $97 \mathrm{~cm}$ higher and occupies the axis of the temple. The total length of these parts is $2.9 \mathrm{~m}$ of $3.8 \mathrm{~m}$ and $6.30 \mathrm{~m}$. Unlike the two first sections which houses two niches respectively, the axial room did not receive any niches; Traunecker, 1994, p.28, fig. 2

Crypt no. 8: is accessible through hall $(\mathrm{H})$. opens in the western end of crypt 6 in the basement of the west wall. It is $4.13 \mathrm{~m}$ long and runs along the undrilled masonry of the foundation and has no niche; Traunecker, 1994, p.30, figs. 2,4

${ }_{90}$ Traunecker, 1994, p. 36; Edfou VII 13(3).

${ }^{97}$ Traunecker, 1994, p. 39, 46, note 58; Cauville, 1983, pp. 26-32, 179, Cauville 1990, pp. 42-44; Among the various osirian celebrations, a festival was consecrated for the cult of Osiris as a water god. This festival was called "the fall of the Nile" or "the festival of Khoiak . The festival of Khoiak, which took place in the fifth month of the Egyptian year (probably between 27 November and 26 December) was annually celebrated between the decline of the Nile flood and the season of harvest; Bonneau, 1964, p. 252, 368; Dunand, \& Zivie- Coche, 1991, pp.311-312; Armour, \& Baker, 1986, p. 45; Rossini, \& Anteleme, 1992, p. 147; Wilkinson, 2000, p.122. 


\section{The Osirian Cult in Temples' Crypts in Egypt during the Greco-Roman Period}

Osirian celebration which were held in Kotpos. Furthermore, rites of the Osirian Khoaik festival were depicted; anointing, purification, and embalming. The second chamber or inner room (room $\mathrm{H}$ ) shows the stages of the rebirth of Osiris which occurred on the $26^{\text {th }}$ of Khoaik symbolizing the renewal of the water cycle vegetation and the astral and royal cycle in ancient Egypt $^{9 \mathrm{~V}}$.

\section{Osiris and the Ritual of Giving Cool Water:}

In the southern crypt no. 2 (chamber $\mathrm{C}$ ) of Denderah temple, four divinities were depicted receiving libations from the king. These deities are; Hathour, Osiris, Isis, and Harsires. The king is depicted pouring water and presenting a vase of plant to Osiris who is depicted here in the standing position and wearing his Atef crown ${ }^{9 \wedge}$ (fig.9).Part of the accompanying texts of the king says;

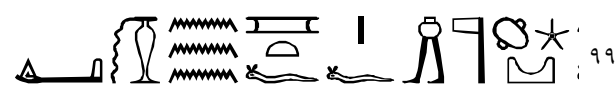

di ḳbhw mrt.f in ntr $d w 3 t$

Giving cool water to him, come god of the other world

The same water libation is practiced by the king in the presence of two seated divinities, namely Harsomtus, and Osiris. This scene is found on the northern wall of the southern crypt no.3 '." (fig.10).

The two scenes reveal the role of a crucial Osirian ritual which is $\Delta \subset\{$ ? di kbhw "giving cool water". Spells from the Pyramid Texts reveal the role of Osiris as the god of the Otherworld who controlled over the cold water in the

Afterlife. He is described to be the only one who can give the deceased king this water. For instance spell 32 of the Pyramid texts says;

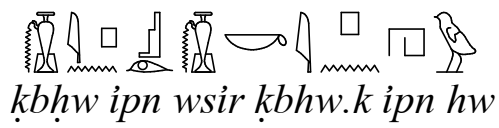

This cold water is yours. Oh, Osiris this cold water of yours '.1

Cauville, , 1983, pp. 31-32.

${ }^{\wedge}$ Dendara VI, pls. CCCCLXXXV, CCCCLXXXIX, DI, pp. 41-44.

${ }^{99}$ Dendara VI, p. 42.

'. Dendara VI, pls. CCCCXCVI, DI, pp. 50-51.

'.' Pyr., 22; Faulkner, 1969, p. 6; Centrone, 2005, pp. 356-357. 


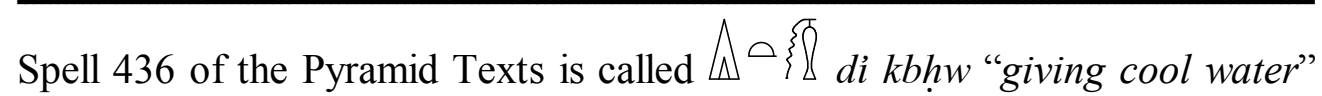
and says;

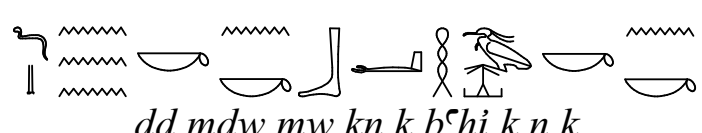

You have your water you have your flood

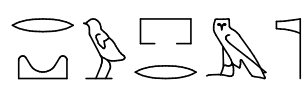

Réw pri m $n \underline{t} r$

The fluid which issued from the god

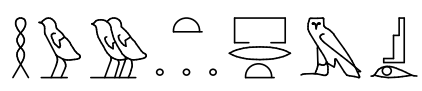

hwt prt $m$ wsir

The exudation which issued form Osiris ${ }^{1 \cdot r}$

This type of waters was subsequently identified with the exudation $(r \underline{d} w)$ coming from Osiris itself. Therefore, the deceased king was purified with the fresh water of Osiris to be resurrected once more in the other world ${ }^{1 . r}$. Therefore, the deceased king was usually depicted offering cool water to Osiris. He confessed that he watered the land of Egypt in the honor of Osiris. This concept was stated in spell 173 of the Book of the Dead as follows; "Oh Osiris, I am your son Horus. I came and I watered the banks. Oh Osiris I am your son Horus. I came and I built canals for you. Oh Osiris I am your son

Horus. I came and I brought to you cold water from Elephantine to make your heart fresh"'.\&.

\section{The Leg of Osiris and the Temples' Crypts}

In Edfu temple, crypts nos. $1^{1.0}$ and $2^{1.4}$ are accessible by the north-east hall $(\mathrm{K})$ "Chapel of the Leg" and were accordingly used to preserve the

\footnotetext{
${ }^{1 . r}$ Pyr ., 788-789; Faulkner, 1969, 143; Similar spells mention the same idea; see spell 553, 536, 553, 676; Centrone, 2005, pp. 356-357.

Centrone, 2005, pp. 356-360.

1. Hornung, 1990, pp. 132,334, 266-270; Centrone, 2005, pp. 356-358.

${ }^{1.0}$ Crypt 1: In the north-west corner of Room K. a 2 meter-deep square passage leads to the crypt which is $95 \mathrm{~cm}$ wide and $3.70 \mathrm{~m}$ long. A high niche with a width of $93 \mathrm{~cm} 63 \mathrm{~cm}$ and a
} 


\section{The Osirian Cult in Temples' Crypts in Egypt during the Greco-Roman Period}

Reliquary of Osiris' Leg ${ }^{1 \cdot v}$ (see fig. 10). The legs of Osiris were one of the sacred relics of this deity. They were mentioned in the Book of the Dead spell 18 as well as the Ramesside pChester Beatty VIII (pLondon BM EA 10688). Part of this document records a magical spell which focuses on the lower parts of Osiris' body; hpd pn hnn pn, rdwy pn, ph pn, ḩ3p pn, $n(y) t$ wsir "that buttock, that phallus, that leg, that behind, and those vital parts of Osiris". All these parts were said to be preserved in a wooden chest in Hierakliopolis ${ }^{1 \cdot \lambda}$. Furthermore, on the outer east wall of the naos of Edfu, the procession of the "right leg and an upper arm" (w'rt wnmyt we rmn is) is mentioned as being the Osirian limb of Hieraklipolis ${ }^{1.9}$.

\section{The $h w t . b n w$ sign}

The hwt.t bnw sign, which was connected with the cult of Osiris, decorates the crypts of the temple of Armant which ". decoration in the lower basement register which consists of the bennu or the phoenix bird with the $h t$ sign and the papyrus plant over which the sun disc is carved" ". The frieze of the $h w . t$ plant over which the phoenix perches symbolized the death of Osiris ${ }^{\prime i r}$. The phoenix bird was connected to the

Osirian cult in ancient Egypt together with the papyrus plant they form the sign of hw.t-bnw $w^{\prime \prime r}$ (fig. 11).

The same decoration is found decorating the walls of the crypts of Denderah temple forming the basement frieze of the wall decoration (see fig.2). For instance, this frieze appeared in the eastern crypt (chamber

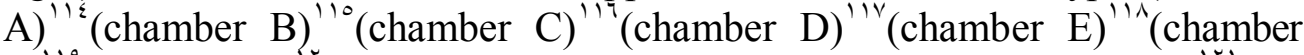
F) ${ }^{1 / 9}(\text { chamber } \mathrm{G})^{r \cdot}$. It appeared also in the southern crypt (chamber A) ${ }^{r 1}$

depth of $63 \mathrm{~cm}$ occupies the center of the north wall $95 \mathrm{~cm}$ above the ground; Traunecker, 1994, p. 28, fig. 2.

Crypt 2: At the eastern end of this crypt, a low passage $(93 \mathrm{~cm})$ leads into the basement crypt of the eastern wall. It has three niches: two in the eastern wall is one at the northern end; Traunecker, 1994, p. 39, 46, note 59; Cauville, 1990, p. 41.

${ }^{1 . \vee}$ Traunecker, 1994, p. 39, 46, note 59; Cauville, 1990, p. 41; Arnold, 1997, p. 216; Watterson, 1998, pp. 72-74; Kurth, 2004, p. 58.

${ }^{1 \cdot \wedge}$ Diaz \& Llanos, 2017, p. 62-63.

1.9 Diaz \& Llanos, 2017, pp. 62-63, 266; Edfou I, 343, 3-8.

". Thiers \& Volokhine, 2005, pp. 10-11; Kakosy, 1982, cols. 1030-1039.

"' Thiers \& Volokhine, 2005, p. 10, fig.20; Waitkus, 2007, p. 342.

"Thiers \& Volokhine, 2005, p. 77; Leitz Chr. (1994). Tagewählerei, Das Buch h3t nhh $p h w y \underline{d} t$ und der verwandte Texte, $\ddot{A} g A b h, 55$, Wiesbaden, pp. 161-163.

Thiers \& Volokhine, 2005, p. 77; for hwt-bnw see; Leahy, 1999, pp.185-192.

"' Cauville, 2004, pl. VIII.

" Cauville, 2004, pl. pl. IX. 
$\left(\right.$ chamber B) ${ }^{r r}(\text { chamber C) })^{1 r r}\left(\right.$ chamber D) ${ }^{1 r \xi}(\text { chamber E) })^{1 r o}$. The same frieze occupies the lower register in the western crypt no.1 (chamber A) ${ }^{r+4}$

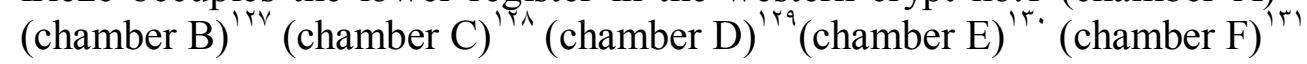

\section{The Khekeru Frieze}

The khekeru sign was a remarkable decorative band which appeared in the Thebean tombs by the Eighteenth dynasty ${ }^{1 / r}$. It consists of three floral elements ${ }^{1+r}$. In Denderah, this frieze decorates the walls of several crypts as a remarkable sign relevant to the cult of Osiris ${ }^{1+\varepsilon}$ (see fig.2). It is found in eastern crypt no. 1 (chamber B) ${ }^{1 \text { to }}$ (Chamber c) ${ }^{\text {ret }}$ (Chamber D) ${ }^{1+t}$ (Chamber

e) ${ }^{1+\lambda}\left(\right.$ Chamber F) ${ }^{1+q}\left(\text { Chamber G) }{ }^{1 \xi \cdot} \text { eastern crypt no. } 2 \text { (Chamber C) }\right)^{1 \xi 1}$ eastern crypt no. $3^{1 \leqslant r}$ eastern crypt no. $4^{1 \leqslant r}$ southern crypt no. $1^{1 \leqslant \varepsilon}$ (chamber

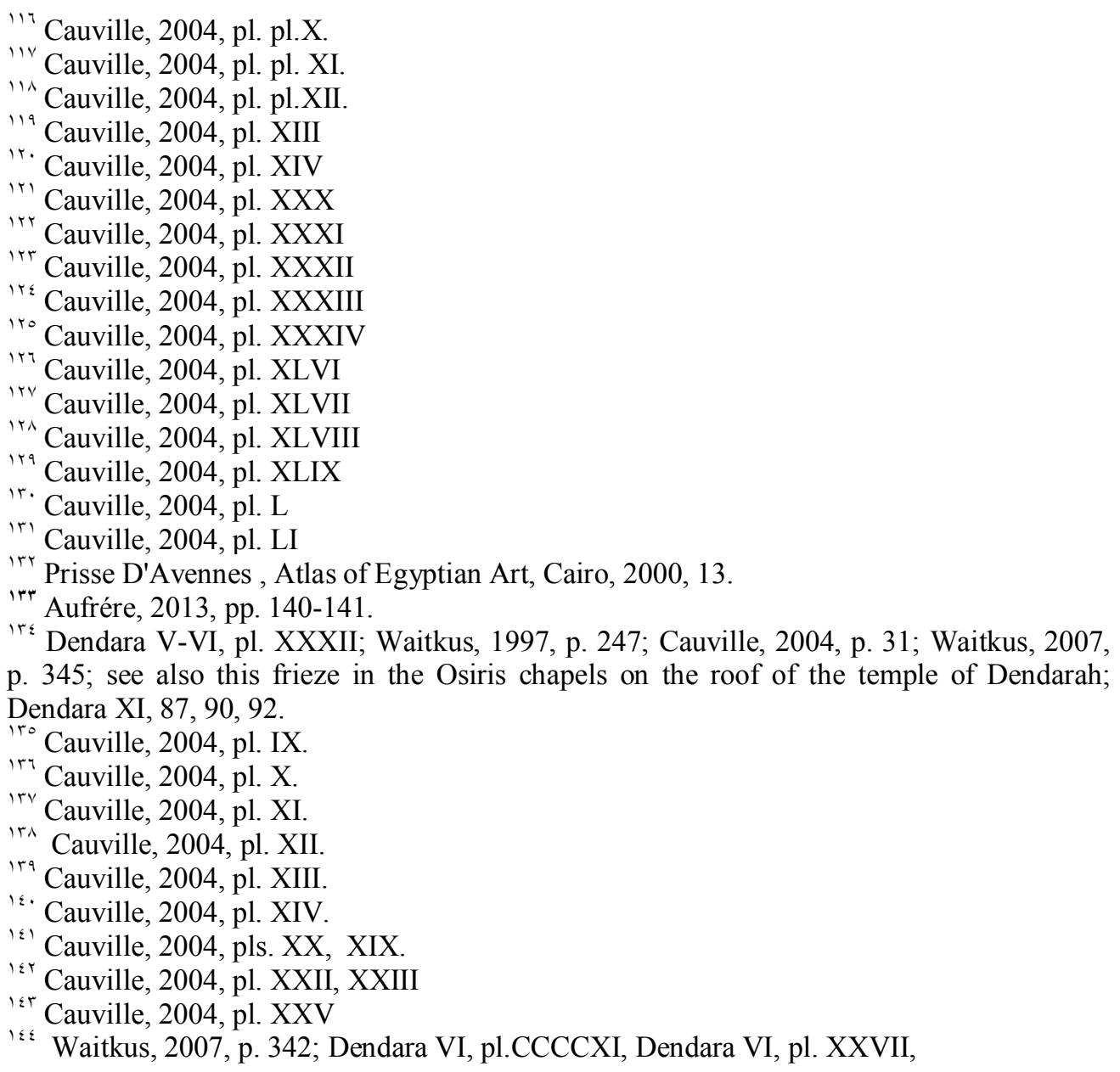


A) ${ }^{1 \leqslant 0}(\text { Chamber B })^{1 \leqslant 4}(\text { Chamber C })^{1 \leqslant v}\left(\right.$ Chamber D) ${ }^{1 \leqslant \wedge}\left(\right.$ Chamber E) ${ }^{1 \leqslant q}$ and the southern crypt no. $3^{10}$. It appeared also in west crypt no. ${ }^{101}$ (Chamber A) ${ }^{104}\left(\right.$ Chamber B/) ${ }^{104}$ (Chamber C) ${ }^{105}$ (Chamber D) ${ }^{100}$ (Chamber E) ${ }^{104}$ (Chamber F) ${ }^{10 v}$ of the same temple. The same khekeru frieze is found decorating the walls of the Osirian chapel on the roof of the temple ${ }^{10 \lambda}$. The chapel no. 2 on the roof of the temple was dedicated to the cult of Osiris where his bodily parts were assembled. ${ }^{109}$. In Armant temple, the khekeru frieze is also found here like the crypts of Denderah ${ }^{17}$. It is located in the north-west corner of the western wall of crypt no.1 and crypt no. $2^{\prime 71}$ (fig. 12).

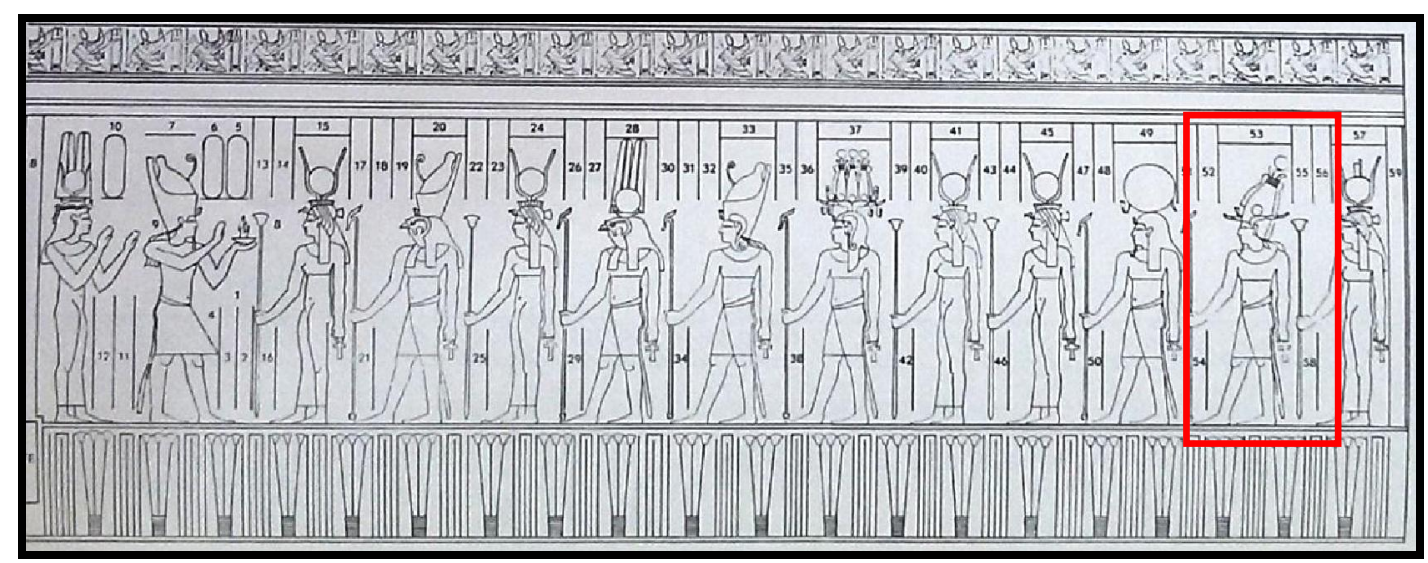

Fig. 1.a. Pantheon of Denderah temple, Denderah temple, west crypt no. 3, east wall

After: Cauville, 2004, pl. LX

\footnotetext{
1కo Cauville, 2004, pl. XXX

Iः Cauville, 2004, pl. pl. XXXI

I\&v Cauville, 2004, pl. XXXII

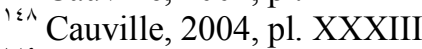

1ะ9 Cauville, 2004, pl. XXXIV

10. Cauville, 2004, pl. XLI

${ }^{101}$ Waitkus, 2007, p. 345.

${ }^{10}$ Cauville, 2004, pl. XLVI

${ }^{10 r}$ Cauville, 2004, pl. XLVII

${ }^{10}$ Waitkus, 2007, p. 345; Dendara VI, pl.XLVIII, DXVII, DXXII

${ }^{100}$ Cauville, 2004, pl. XLIX

${ }^{104}$ Cauville, 2004, pl. L

lov Cauville, 2004, pl. LI, LII

${ }^{10 \wedge}$ Thiers, \& Volokhine, 2005, p. 77; Dendara X, 151-153; 249-251.

${ }^{109}$ Kaper, 2008-2009, pp. 31-32.

17. Waitkus, 2007, 345.

17' Thiers, \&Volokhine, 2005, p. 11, figs .20, 13.
} 


\section{Sara El-Sayed Kitat}

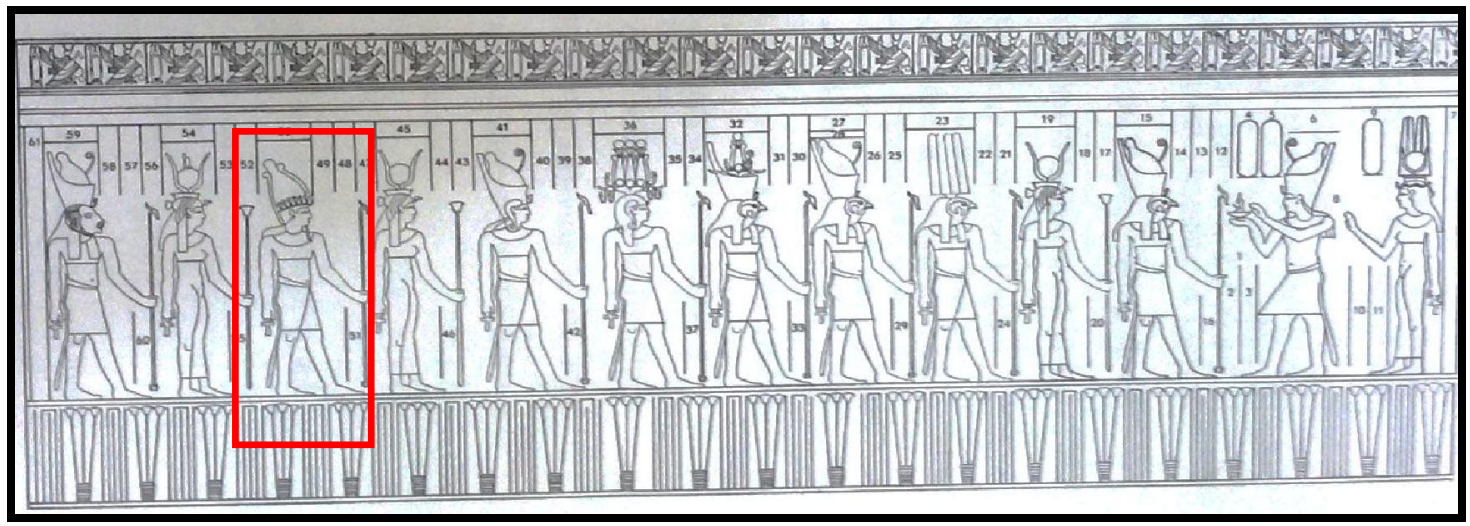

Fig. 1.b. Pantheon of Edfu temple, Denderah temple, west crypt no. 3, west wall

After: Cauville, 2004, pl. LXI

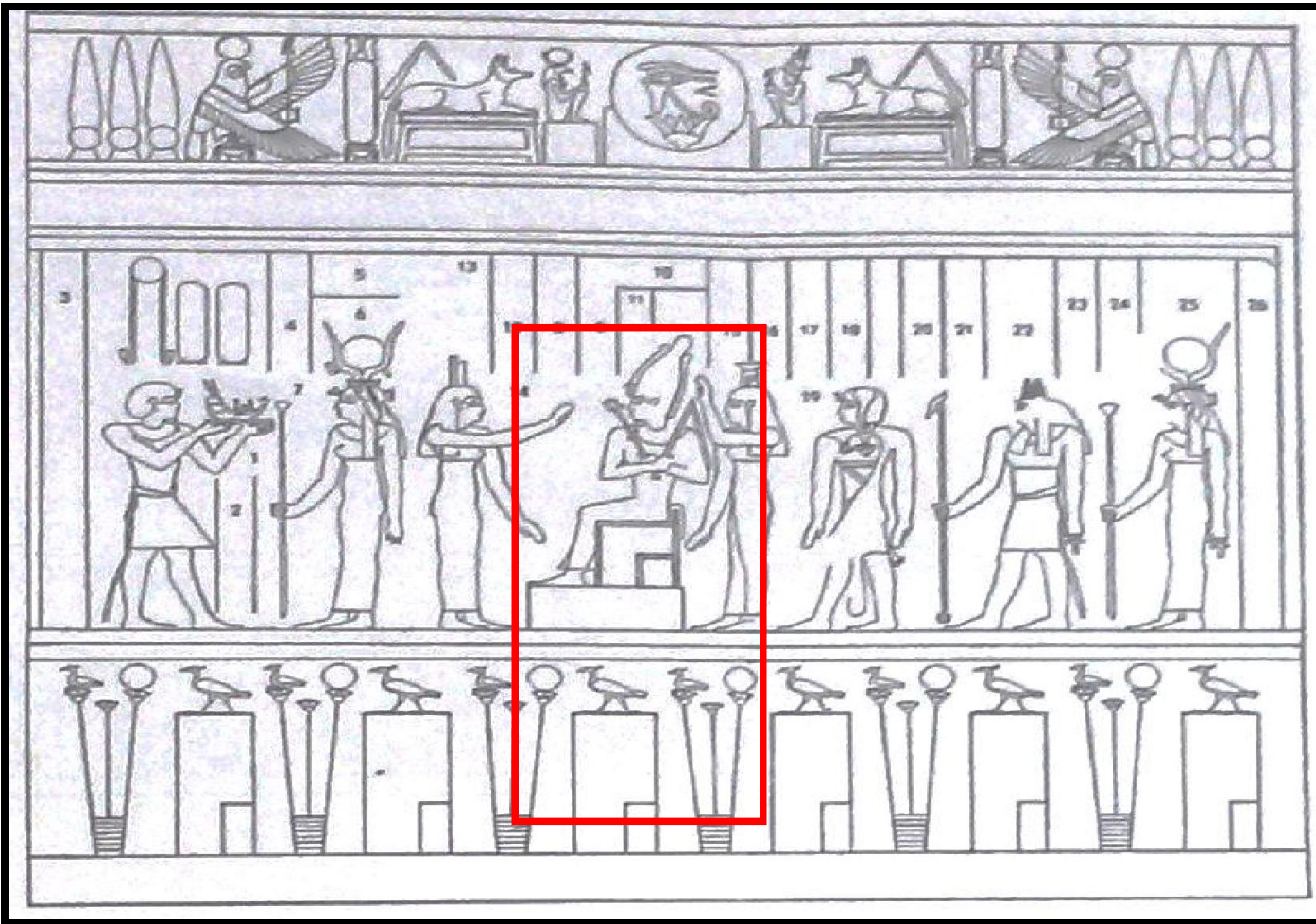


The Osirian Cult in Temples' Crypts in Egypt during the Greco-Roman Period

Fig. 2. Osiris enthroned and flanked by Isis and Nephtys, the upper register

bears the Khekeru sign and the lower register shows the hwt bennu sign,

western Crypt no. 1 (chamber C), eastern wall, Denderah temple, Ptolemaic

period

After: Denderah VI, pl. XLVII

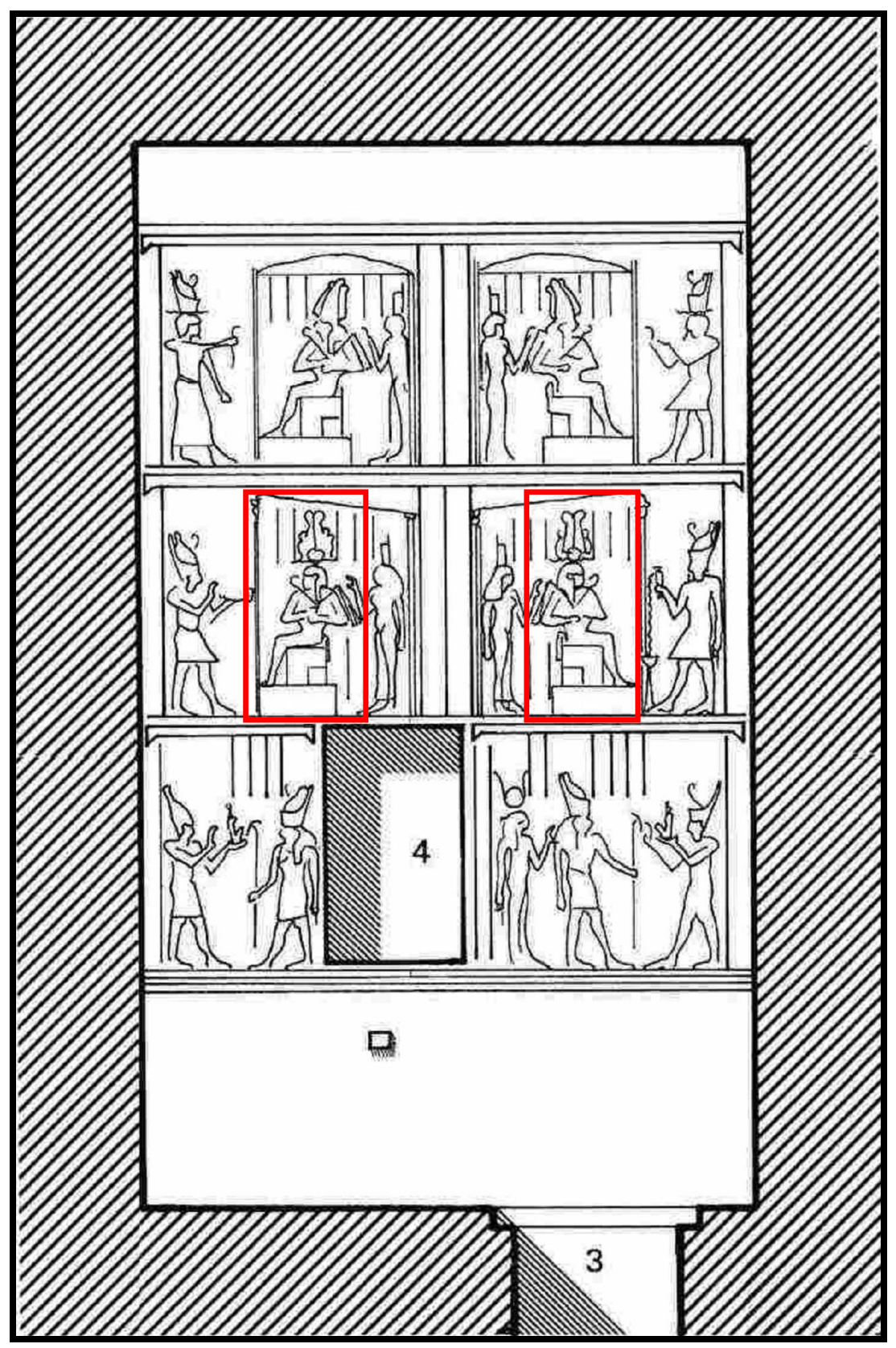


Fig.3. Osiris enthroned and flanked by Isis and Nephtys, west wall of room $\mathrm{H}$, Edfu temple, Ptolemaic period

After: Traunecker, 1994, p. 29, fig.3

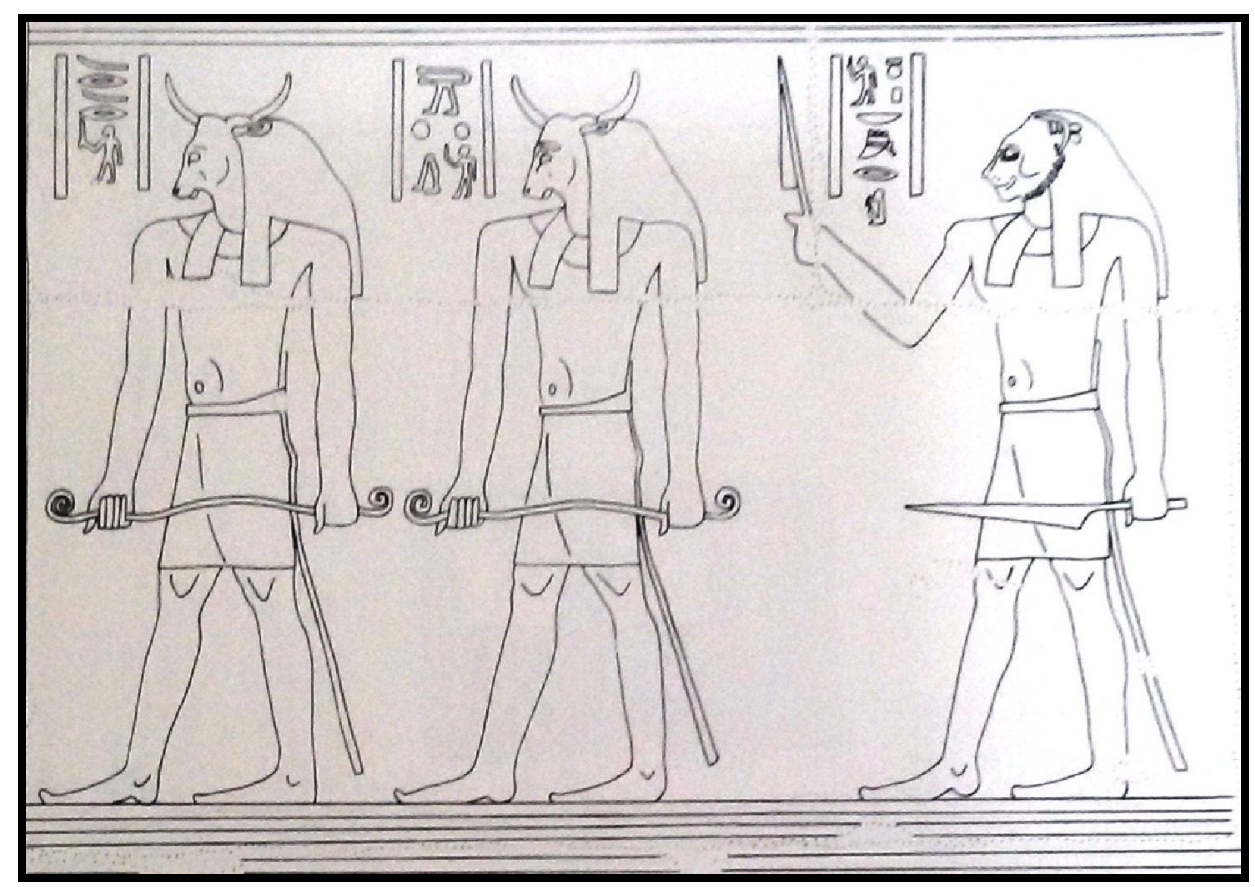

Fig. 4. a. bull- headed deities holding ropes followed by a lion-headed god holding two knives, south wall of Crypt no. 1, Armant Temple, Ptolemaic period

After: Thiers \& Volokhine, 2005, fig.50

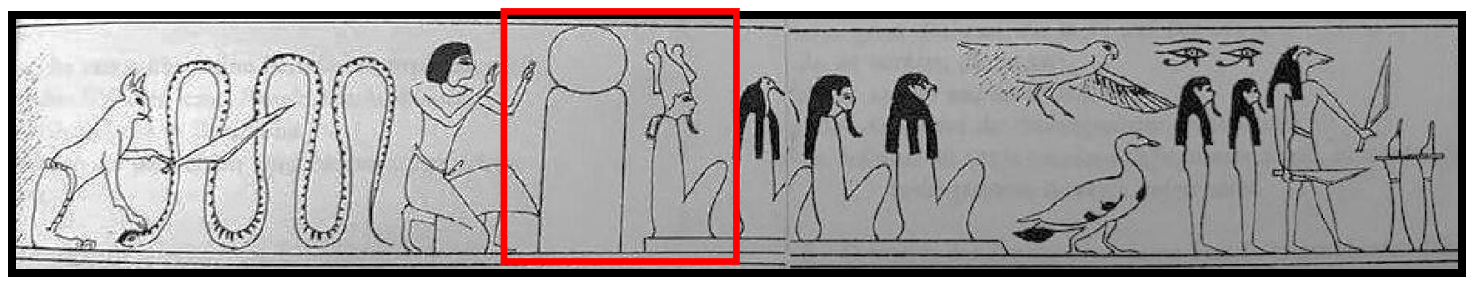

Fig.4.b.Osiris and his slaughter house, Chapter 17, Book of the Dead

After: Hornung, 1990, pp. 76-77 


\section{Period}

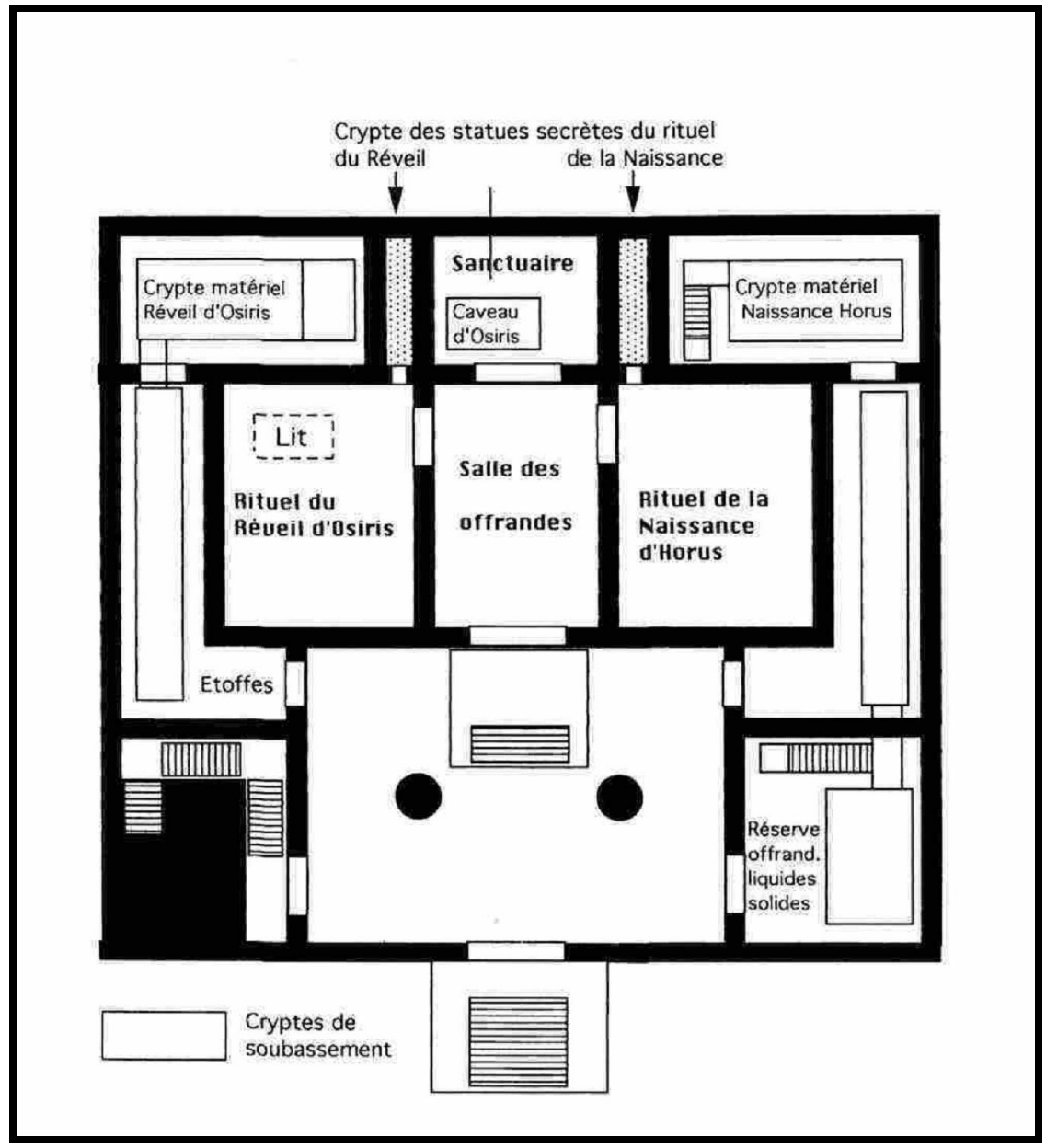

Fig.5. Crypts of the temple of Opet, Karnak Temple, Ptolemaic Period After: Traunecker, 1994, p. 41, fig.7 


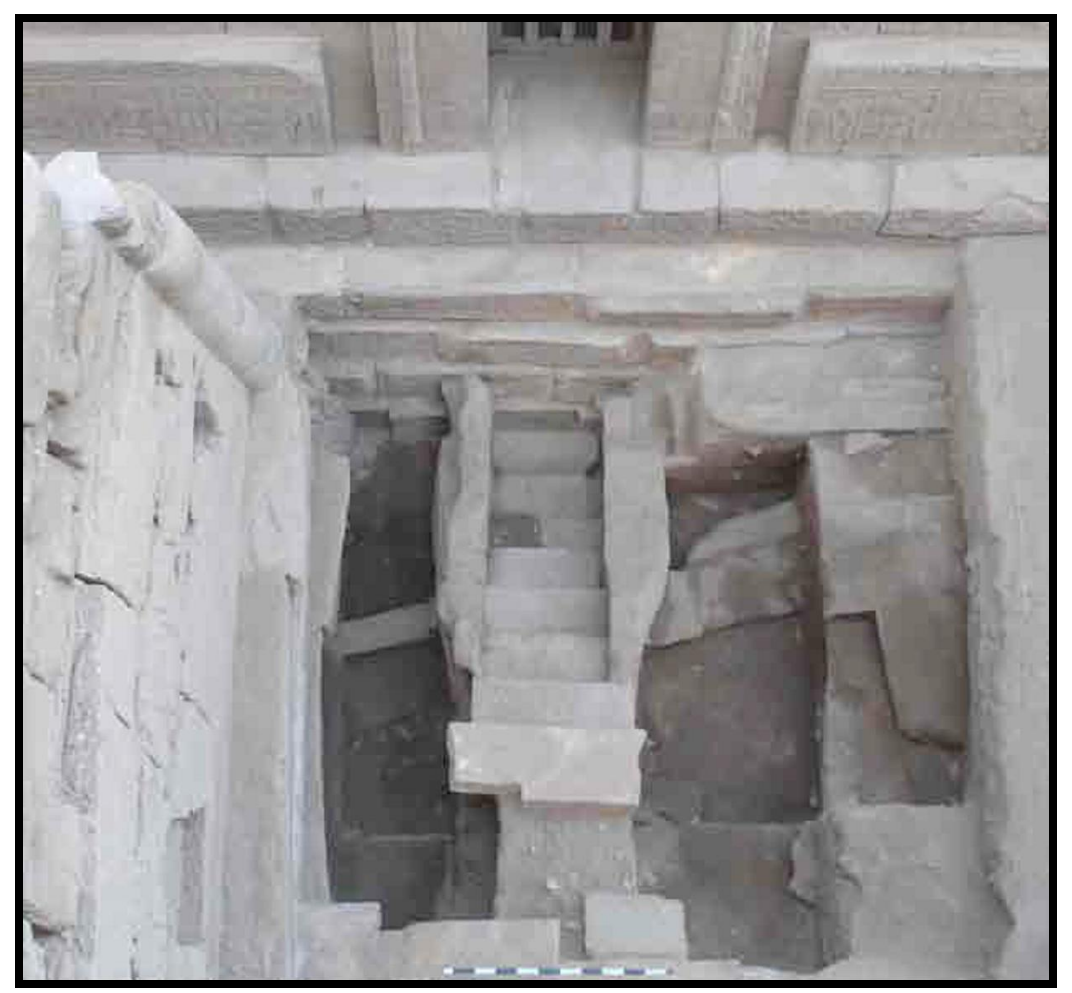

Fig. 6. The discovered staircase at the rear back of Opet temple at Karnak After: Supreme Council of Antiquities, Ministère des Affaires Étrangères, Européennes, et Centre National de la Recherche Scientifique, \& FrancoEgyptian Center of the Temples of Karnak, 2008, p. 13 


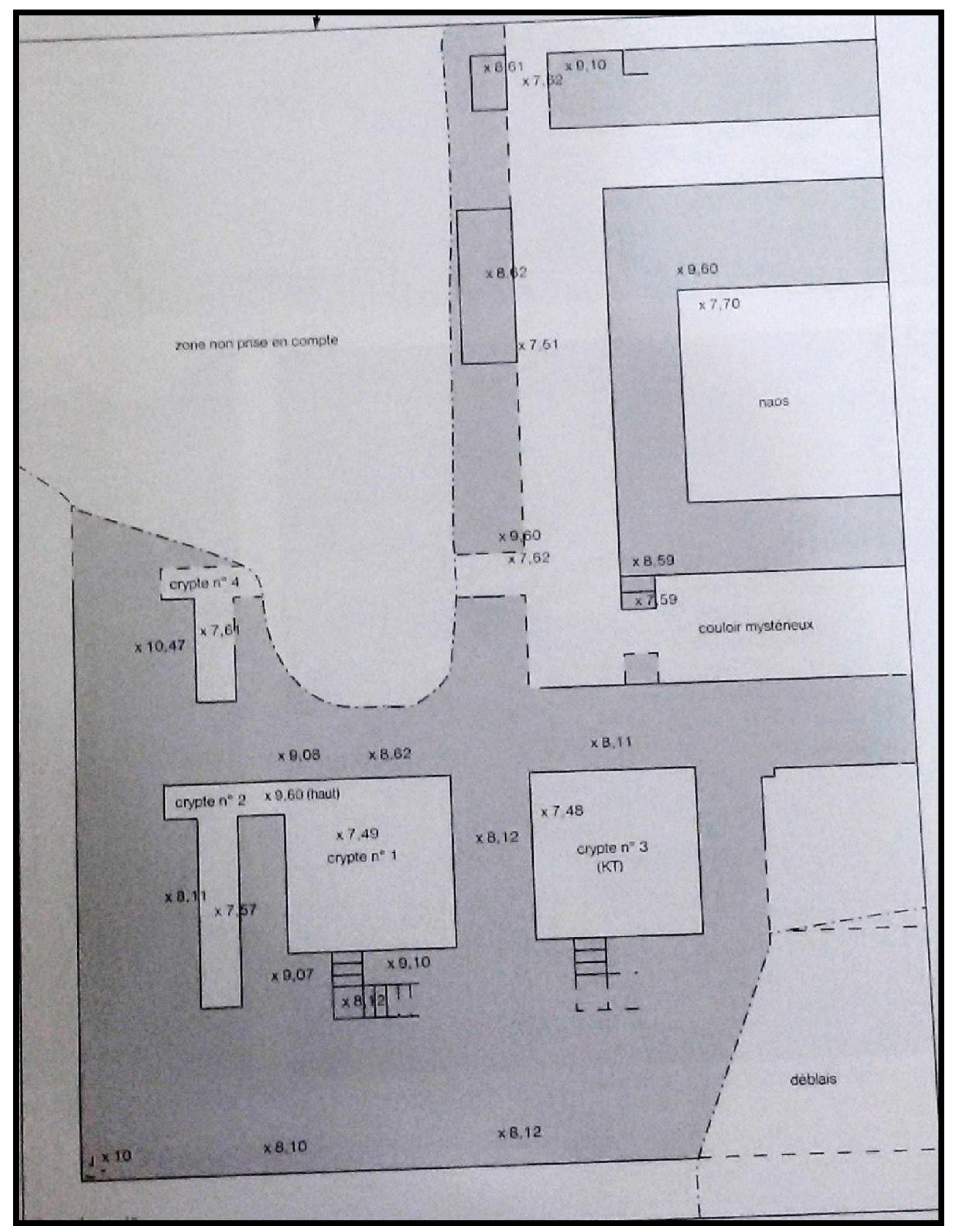

Fig.7. Plan of the crypt of Armant temple, Ptolemaic period After: Thiers, \& Volokhine, 2005, fig.1. 


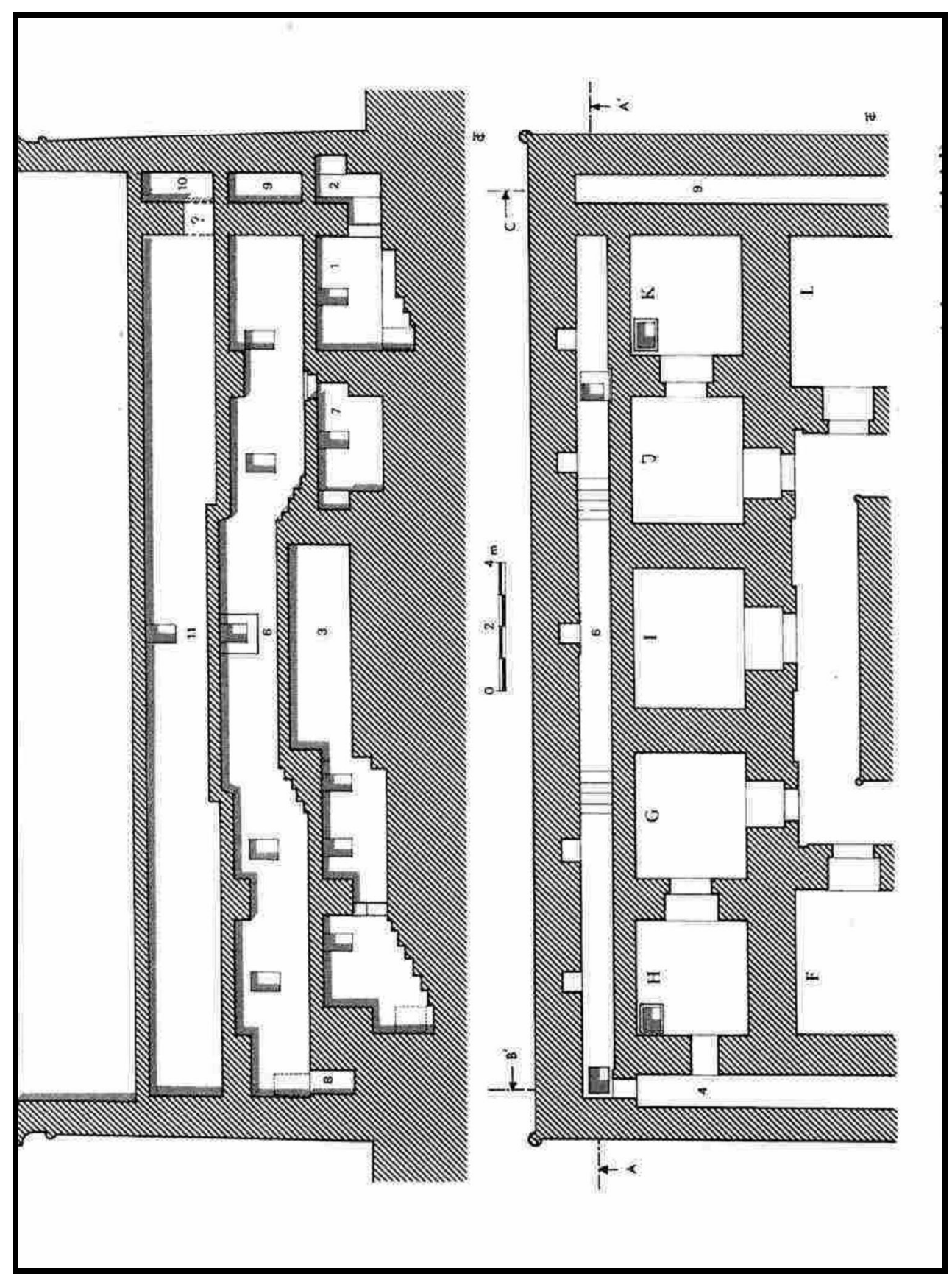

Fig.8. General plan of crypts of Edfu temple

After: Traunecker, 1994, p. 27, fig. 2 


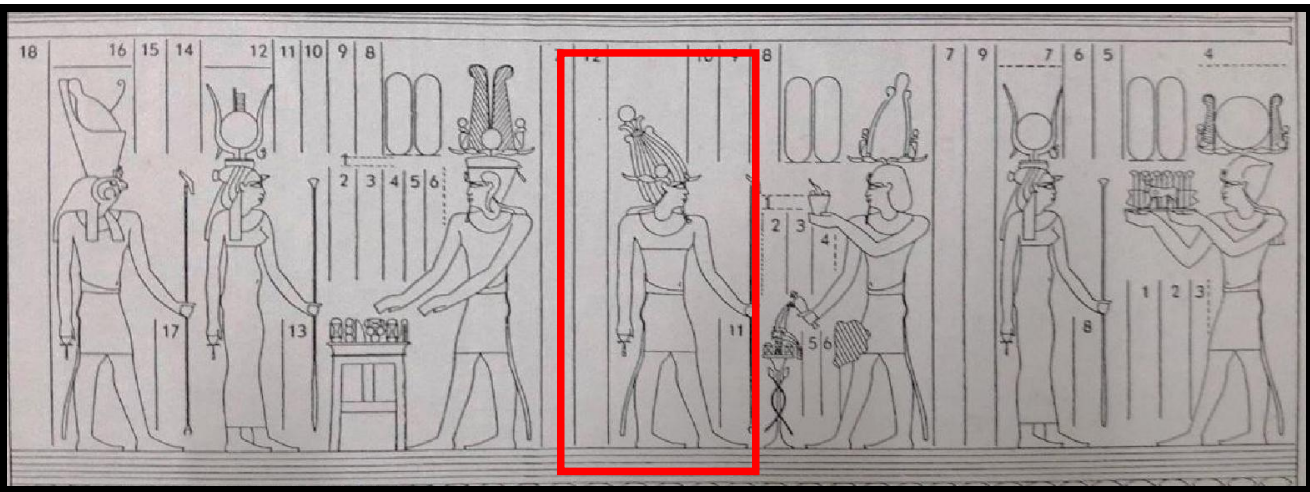

Fig. 9.Hathour, Osiris, Isis, and Harsires receiving offerings from the king, southern Crypt no. 2 (chamber C), northern wall, Denderah temple,

Ptolemaic period

After: Denderah VI, pl. CCCCLXXXV

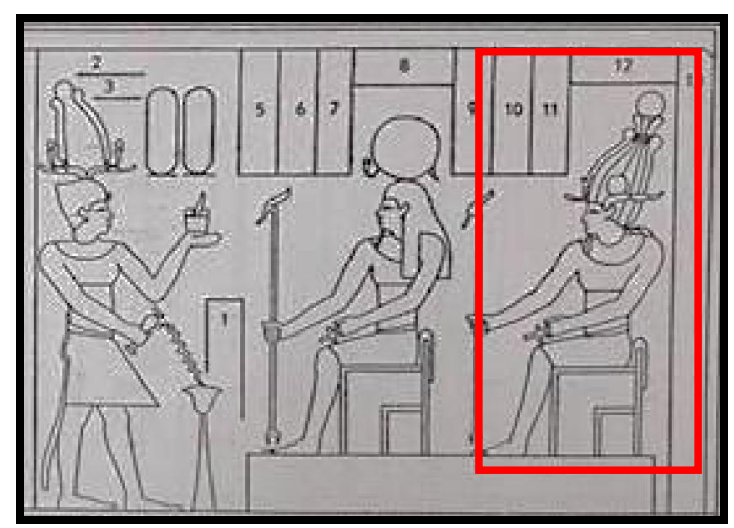

Fig. 10.Harsomtus and Osiris, receiving water libation from the king, northern wall, southern Crypt no. 3,Denderah temple, Ptolemaic period After: Denderah VI, pl. CCCCXCVI 


\section{Sara El-Sayed Kitat}

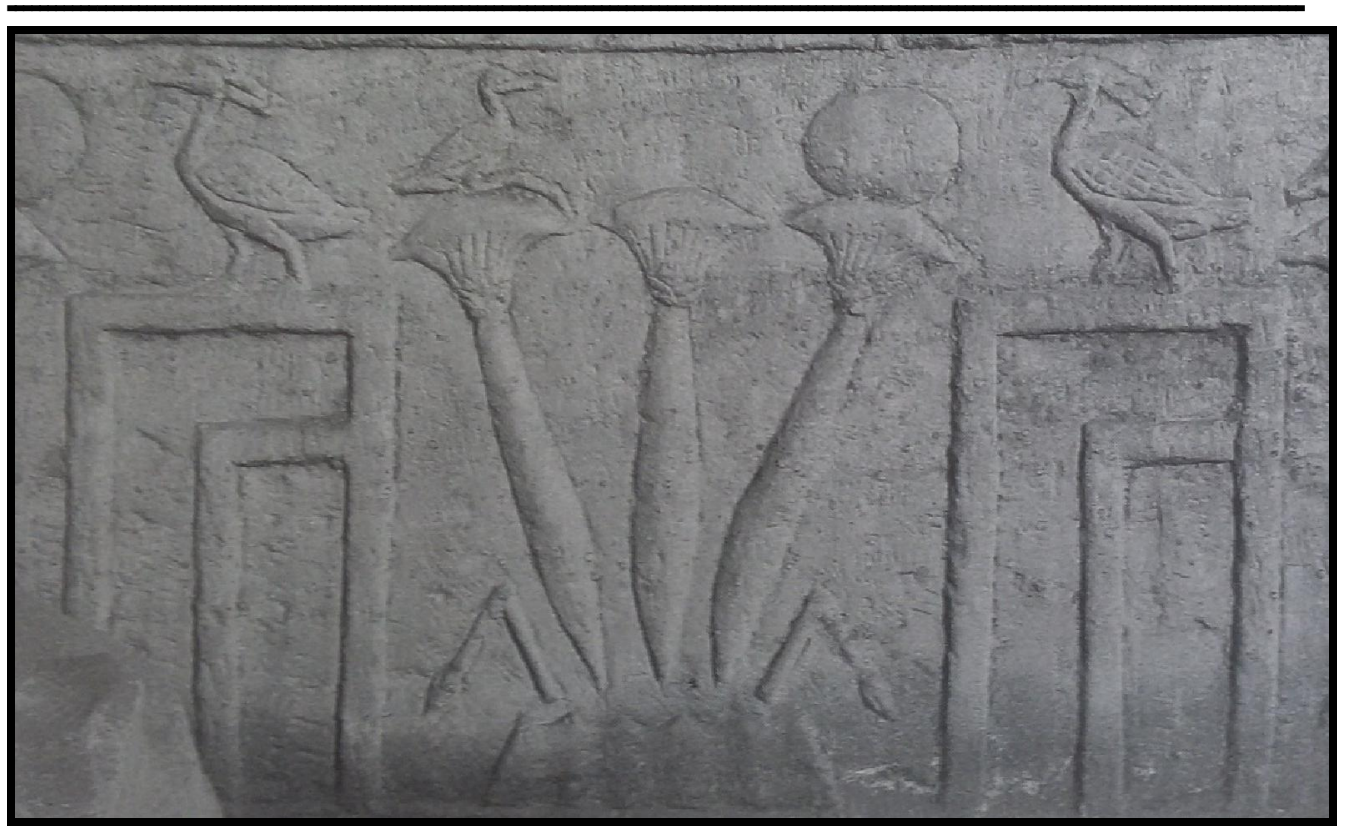

Fig.11. The ḩwt bennu sign, Basement register, west wall, Crypt no.3,

Armant temple, Ptolemaic period

After: Thiers, \& Volokhine, 2005, p. 24, fig. 37.

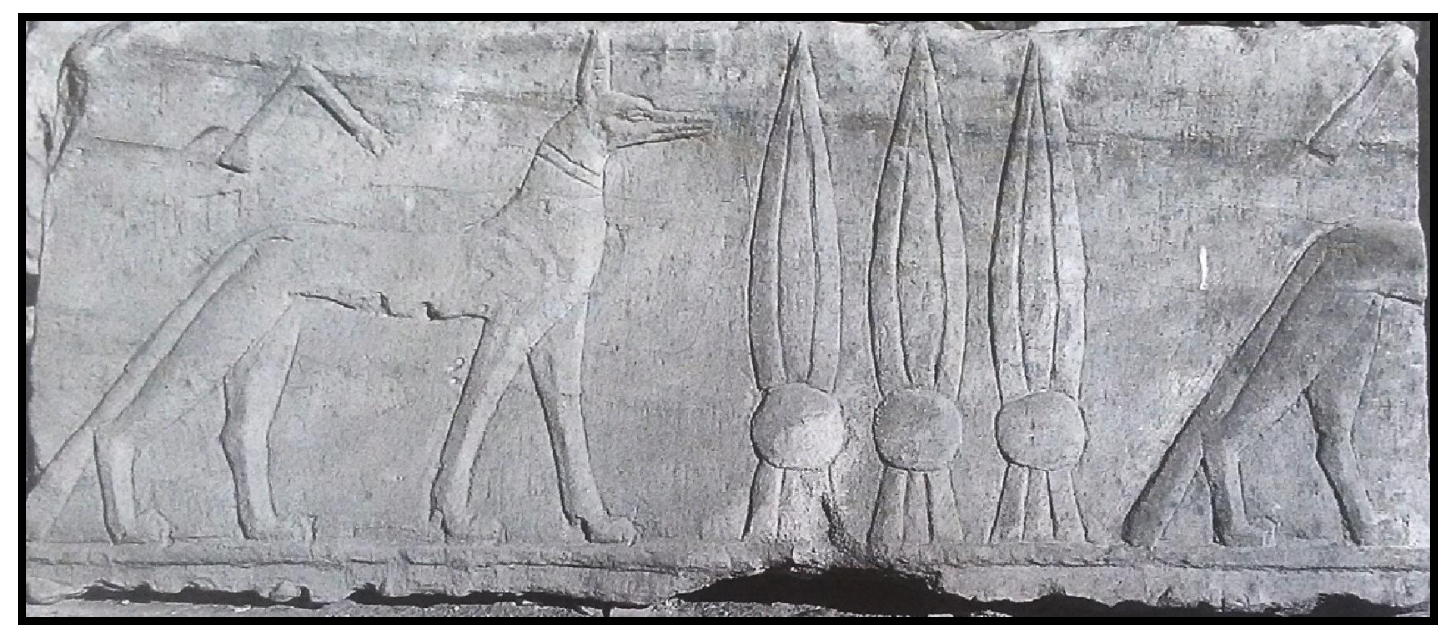

Fig.12. The khekeru sign as a basement frieze, west wall, crypt no. 1, Armant temple, Ptolemaic period

After: Thiers, \& Volokhine, 2005, p. 19, fig.20. 


\section{References}

- Alliot M. (1949-1954). Le culte d'Horus à Edfou au temps des Ptolémées; two volumes, BiEtud, 20, pp. 303-433.

- Armour R. A., \& Baker A. (1986). Gods and Myths of Ancient Egypt. $2^{\text {nd }}$ ed. Cairo: American University Press.

- Arnold D. (1997). Royal Cult Complexes of the Old and Middle Kingdoms. In: B. E. Shafer, D. Arnold, G. Haeny, L. Bell, \& R. B. Finnestad (Eds.). Temples of Ancient Egypt. New York: I. B. Taurus, pp. 31-85.

- Aufrére, S. H. (2013). An Attempt to Classify Different Stages of Intertextuality in the Myth of Horus at Edfu. In M. Bauks, W. Horowitz, \& A. Lange (Eds.). Between Text and Text: The Hermeneutics of Intertextuality in Ancient Cultures and their Artifacts in Mediaval and Modern Times. Göttingen: Vandenhoek \& Ruprecht, pp. 140-141.

- Barguet P., (1962). Le papyrus N. 3176 (S) du muse du Louvre, BdE, 37. Le Caire.

- Bonneau D. (1964). La crue du Nil, divinité égyptienne, à travers mille ans d'histoire (332 av.-641 ap. J.-C.). Paris: Paris: Librairie C. Klincksieck.

- Bonnet H. (2000). Reallexikon. Berlin: New York: de Gruyter.

- Cauville S. (1983). La Théologie d' Osiris à Edfou, Le Caire: IFAO.

- Cauville S. (1984). Edfou. Bibliothèque générale 6. Le Caire: IFAO.

- Cauville S. (1987). Les statues cultuelles de Dendera d'après les inscriptions parietals (avec 5 planches). BIFAO, 87, pp. 73-117.

- Cauvile S. (1990). Le Temple de Dendara: Guide archéologique, Tome XII, Le Caire: IFAO.

- Cauville S. (1997). Dendara X. Les chapelles osiriennes: textes hiéroglyphiques. Le Caire, IFAO.

- Cauville S. (1997). Dendara, 'Les chapelles osiriennes. Commentaire, BdE, 118.

- Cauville S. (2002). Dendara: Les fêtes d'Hathor, OLA 105, Leuven.

- Cauville S. (2004). Dendara V-VI; Traduction; Les Cryptes du Temple d'Hathour, OLA 131, Leuven.

- Cauville S., (2008). Karnak ou la quintessence de l'Egypte, BSFE, 172, pp. 17-31.

- Centrone, M. C. (2005). This is the Form of [....] Osiris of the Mysteries who Springs from the Returning Waters (South Wall of the Osiris Room at the Great Temple of Philae). In: A. Alessia (Ed.). $L^{\prime}$ Acqua Nell' Antico Egitto, Proceedings of the First International 
Conference for Young Egyptologists, Italy October 15-18, 2003. Roma: L' Erma di Breatschneider, pp. 355-360.

- Charloux, G. (2006-2007). Conclusion. In: G. Charloux, R. Angevin, S. Merchand, H. Monchot, A. Oboussier, J. Roberson, \& H. Vernque (Eds.). Le Parvis du Temple d'Opet a Karnak; Exploration archéologique (2006-2007), Exploration archéologique, Centre Franco-Égyptien d'étude des Temples de Karnak https://www.academia.edu/4807361/Le_parvis_du temple_d_Opet $\%$ C3\% A0 Karnak. Exploration arch\%C3\%A9ologique 20062007 BiGen_41_IFAO_2012 [Accessed on 22 September 2016], pp 253-288.

- Chassinat, É., Chassinat, É., Daumas, Fr., \& Cauville S. (1947-1952). Le Temple de Dendara, Tome, $V$. Le Caire: IFAO.

- Chassinat, É., Chassinat, É., Daumas, Fr., \& Cauville S. (1965). Le Temple de Dendara, Tome VI. Le Caire: IFAO.

- Coppens F. (2009). Temple Festivals of the Ptolemaic and Roman Periods. In: W. Wendrich, J. Dieleman, E. Frood, \& J. Baines (Eds.). UCLA Encyclopedia of Egyptology, (http://escholarship.org/uc/item/4cd7q9mn) [Accessed on December 2016], pp.1-11.

- Daumas Fr. (1951). Sur trois representations de Nout a Dendara, ASAE, 51, pp. 373-400.

- Daumas Fr. (1969). Dendara et le temple d'Hathor: Notice sommaire. Recherches d'archéologie, de philologie et d'histoire, 23. Le Caire: IFAO, pp. 62-63.

- D'Avennes P. (2000). Atlas of Egyptian Art. Cairo: American University Press.

- Degardin J.- Cl., (1985). Correspondances osiriennes entre les temples d'Opet et de Khonsou, JNES, 44, pp. 115-131.

- Degardin, J.-Cl., (2006-2007). Opet et Khonsou. In: G. Charloux, R. Angevin, S. Merchand, H. Monchot, A. Oboussier, J. Roberson, \& H. Vernque (Eds.). Le Parvis du Temple d'Opet a Karnak; Exploration archéologique (2006-2007), Exploration archéologique, Centre Franco-Égyptien d'étude des Temples de Karnak, pp. 283-285

- Degardin, J.-Cl. (2010). Le fonctionnement du toit tu temple de Khonsou à Karnak, Cahires de Karnak 13, pp. 227-241.

- De Meyer M., \& Minas-Nerpel M. (2012). Temple of Shenhur. In: W. Wendrich, J. Dieleman, E. Frood, \& J. Baines (Eds). UCLA Encyclopedia of Egyptology, http://escholarship.org/uc/item/5hc3t8dh [ Accessed on: 10 March 2017], pp. 1-9. 


\section{The Osirian Cult in Temples' Crypts in Egypt during the Greco-Roman Period}

- De Rochemonteix M., Chassinat É., Cauville S., \&Devauchelle D. (1984-1987). Le Temple d'Edfou, Tome I, II. Le Caire: IFAO.

- De Rochemonteix M., Chassinat É., Cauville S., \&Devauchelle D. (1990). Le Temple d'Edfou, Tome II. Le Caire: IFAO.

- De Rochemonteix M., Chassinat É., Cauville S., \&Devauchelle D. (1993). Le Temple d'Edfou, Tome VII. Le Caire: IFAO.

- De Witt C. (1958). Les Inscriptions du temple d'Opet à Karnak I, BiAeg 11, Bruxelles.

- De Wit C. (1968), Les inscriptions du temple d'Opet, à Karnak, III. Traduction intégrale des textes rituels. Essai d'in terprétation, BiAeg, 13, Bruxelles.

- Diaz L., \& Llanos L. (2017). Naref and Osiris Naref: A Study in Herakleopolitan Religious Traditions. Berlin: Walter de Gruyter,

- Dunand F., \& Zivie - Coche C. (1991). Dieux et Hommes en Égypte 3000 av.J-C 395 apr. J. C. Paris: Armand Colin.

- Fairman R W. (1954-1955). Worship and festivals in an Egyptian temple, BJRL, 37, pp. $165-203$.

- Faulkner R. O. (1969). The Ancient Egyptian Pyramid Texts. Oxford: Clarendon Press.

- Finnestad R. B. (1997). Temples of the Ptolemaic and Roman periods: Ancient Traditions in New Contexts. In: B. E. Shafer, D. Arnold, G. Haeny, L. Bell, \& R. B. Finnestad (Eds.). Temples of Ancient Egypt. New York: I. B. Taurus, pp. 185-238.

- Goyon J. C., (1972). Rituels funéraires de l'ancienne Égypte, LAPO 4, Paris, pp. 296-299.

- Goyon J- Cl. (1999). Le Papyrus d'Imouthes, fils de Psintaês au Metropolitan Museum of Art de New-York (Papyrus MMA 35.9.21). New York: Metropolitan Museum of Art.

- Griffiths J. G. (1982). Osiris, L̈̈, IV, Wiesbaden: Harrassowitz, cols. 623-633.

- Herbin Fr. R. (2003). La renaissance d'Osiris au temple d'Opet (P. Vatican Inv. 38608), RdE, 54, pp. 67-127

- Hoffman F. (2002). Measuring Egyptian Statues. In: J. M. Steele, \& A. Imhausen (Eds.), Under One Sky. Astronomy and Mathematics in the Ancient Near East, AOAT 297, pp. 109-119.

- Hornung E. (1990). Das Totenbuch der Ägypter. München: Artemis Verlag.

- Kakosy L. (1982). Phönix, L̈̈, IV. Wiesbaden: Harrassowitz, cols. 1030-1039.

- Kaper O. (2008-2009). A Fragment from the Osiris Chapels at Dendeara in Bristol, JEOL, 41, pp. 31-32 
- Kurth D., (2004). The Temple of Edfu: a Guide by an Ancient Egyptian Priest. Cairo: American University Press.

- Leahy A. (1999). In the House of the Phoenix at Thebes (Cairo JE 36938). In: A. Leahy, \&J. Tait (Eds.). Studies on Ancient Egypt in Honour of H. S. Smith. London: Egyptian Exploration Society, pp.185-192.

- Leitz Chr. (1994). Tagewählerei, Das Buch h3t nhhh phwy $\underline{d} t$ und der verwandte Texte, $\ddot{A g} A b h, 55$, Wiesbaden, pp. 161-163.

- Mallet D. (1888). Le Culte de Neith à Sais. Paris: Ernest Leroux.

- Mendel D.,(2003). Die kosmogonischen Inschriften in der Barkenkapelle des Chonstempels von Karnak, MRE, 9, Turnhout.

- Meunier M. (1942). Plutarch, De Iside et Osiride. Paris: L'Artisan du livre.

- Moharram, H. (2000). Hall of Ht wabt and Hall of Ht IHy $(k)$ and the Two Halls of the south chamber no.1; Ht wabt (d) and Ht IHy (E); Linguistic Cultural Study, unpublished PhD. Dissertation. Cairo University: Faculty of Archaeology.

- Murray M. M. (1931). Egyptian Temples, New York: Dover Publications.

- Pieron H. (1910). Les chambres secrètes du Mammisi de Dendéra, BIFAO, 7, pp. 71-76.

- Roulin G. (1996). Le Livre de la Nuit. Une composition égyptienne de l'au-delá, OBO 147/1-2. Fribourg: Édition Universitaires: Göttingen: Vandenhoeck \& Ruprecht.

- Rossini S.,\& Anteleme R. S.(1992). Neter Dieux d'Égypte. France: Trismegiste.

- Sethe K. (1908). Die Ägyptische Pyramidentexte nach den papierdrücken und Photographien des Berliner Museums, vols. I, II. Hildescheim: Geaorg Olms Verbuchverhandlung,.

- Traunecker C. (1980). Krypta, LÄ III, Wiesbaden: Harrassowitz, cols. 823-830.

- Traunecker C. (1994), Cryptes Connues et Inconnues des Temples Tardifs. BSFE, 129, pp. 21-46.

- Traunecker C. (1995). Les ouabet des temples d'el-Qal'a et de Chenhour: Décoration, origine et evolution. In: D. Kurth (Ed.) 3. Ägyptologische Tempeltagung (Hamburg, 1. - 5. Juni 1994), Systeme und Programme der ägyptischen Tempeldekoration, Ägypten und Altes Testament, 33. Wiesbaden: Harrassowitz, pp. 241 - 282.

- Thiers Ch.\& Volokhine Y. (2005). Ermant I: Les crypts du temple ptolémaïque, Étude épigraphique, MIFAO, (124). Le Caire: IFAO. 
- Varille A. (1942). Inventaire d'objets cultuels d'un temple thébain de Maqat, BIFAO, 41, pp. 135-139.

- Von Dassow E. (2008). The Egyptian Book of the Dead; The Book of Going Forth by Day, the Complete Papyrus of Ani featuring Integrated Text and Full-color Images. San Francisco: Chronicle Books.

- Waitkus W. (1997). Die Texte in den unteren Krypten des Hathortempels von Dendara: Ihre Aussagen zur Funktion und Bedeutung dieser Räume. Münchner Ägyptologische Studien, 47. Mainz: Philipp von Zabern.

- Waitkus W. (2007). Faraonisch Egypte, BiOr LXIV, n. 3-4, pp. 342346.

- Watterson B. (1998). The House of Horus at Edfu: Ritual in an Ancient Egyptian Temple. Stroud: Tempus.

- Wiedemann A. (1903) Osiris végétant. Paris: Le Muséon.

- Wilkinson R. (2000). The Complete Gods and Goddesses of Ancient Egypt. Cairo: American University Press.

- Winlock H.E. (1938-1941)., The Temple of Hibis I. New York: Metropolitan Museum of Art.

- Zivie-Coche Chr., (1986). Deir Chelouit III 90-157; Inscriptions du naos. Le Caire: IFAO. 